TITLE:

\title{
The Synthesis of Alkaloids Using Transition-Metal-Catalyzed Intramolecular Amination Reactions
}

\section{$\operatorname{AUTHOR(S):~}$}

Ohno, Hiroaki; Chiba, Hiroaki; Inuki, Shinsuke; Oishi, Shinya; Fujii, Nobutaka

\section{CITATION:}

Ohno, Hiroaki ... [et al]. The Synthesis of Alkaloids Using Transition-Metal-Catalyzed Intramolecular Amination Reactions. Synlett 2014, 25(02): 179-192

\section{ISSUE DATE:}

2014-01-13

URL:

http://hdl.handle.net/2433/196783

\section{RIGHT:}

(c) Georg Thieme Verlag Stuttgart · New York; This is not the published version. Please cite only the published version.; この論文は出版社版で ありません。引用の際には出版社版をご確認ご利用ください。 


\title{
The Synthesis of Alkaloids Using a Transition-Metal-Catalyzed Intramolecular Amination Reaction
}

\author{
Hiroaki Ohno, * Hiroaki Chiba, Shinsuke Inuki, Shinya Oishi, Nobutaka Fujii* \\ Graduate School of Pharmaceutical Sciences, Kyoto University, Sakyo-ku, Kyoto 606-8501, Japan \\ Fax: (+81) 75-753-4570 \\ E-mail: hohno@pharm.kyoto-u.ac.jp; nfujii@pharm.kyoto-u.ac.jp \\ Received: The date will be inserted once the manuscript is accepted.
}

\begin{abstract}
Transition-metal catalyzed reactions have the potential to provide significant improvements to the syntheses of complex target molecules. These reactions can be used to achieve a variety of different atom-economical transformations and cascade reactions and therefore provide access to synthetic strategies that would otherwise be unavailable using classical organic chemistry. To exemplify the utility of the latest transition metal catalyzed reactions for the construction of important target structures, we have been involved in total synthesis of natural products bearing widely known chemical scaffolds. In this account, we report our recent studies on the use of a palladium-catalyzed cascade cyclization reaction and a gold(I)-catalyzed hydroamination reaction, for the construction of the core structures of alkaloids, as well as their application to total syntheses of lysergic acid, lysergol, isolysergol, and quinocarcin.
\end{abstract}

1 Introduction

2 Ergot Alkaloid Synthesis

2.1 Construction of the Core Structure by PalladiumCatalyzed Cascade Cyclization

2.2 Asymmetric Total Syntheses of (+)-Lysergic Acid and Related Alkaloids

3 Quinocarcin Synthesis

3.1 Construction of the Core Structure by Gold-Catalyzed Hydroamination

3.2 Asymmetric Total Synthesis of (-)-Quinocarcin

4 Concluding Remarks

Key words: Total synthesis, palladium, gold, alkaloids, atom economy

\section{$1 \quad$ Introduction}

Making improvements to the step and atom economies of organic transformations is one of the most important requirements in modern organic chemistry. ${ }^{1}$ Transition metal catalysts have had a significant impact on the facility with which organic chemists can access complex target structures by providing synthetic strategies for the construction of target molecule that would otherwise be difficult or even impossible to access using classical organic chemistry. To demonstrate the power of transition metal catalysis in organic chemistry, we have been working towards the synthesis of natural products using transition-metal-catalyzed cyclization reactions. A series of well-known chemical scaffolds were selected as the targets of our study including those of the ergot alkaloids (e.g., lysergic acid, lysergol, and isolysergol) and the tetrahydroisoquinoline alkaloids (e.g., quinocarcin). Although several efficient total syntheses of these natural products have already been reported (for details, see the introduction text of sections 2 and 3), our current approach represents a unique strategy that sometimes provide improvements in the step and atom economies of the syntheses of these compounds, as well as providing a platform for the synthesis of other complex natural products. Herein, we describe our recent work towards the synthesis of ergot alkaloids using a palladiumcatalyzed cascade cyclization of allenes, as well as a gold(I)-catalyzed hydroamination for the synthesis of tetrahydroisoquinoline alkaloids.

\section{$2 \quad$ Ergot Alkaloid Synthesis}

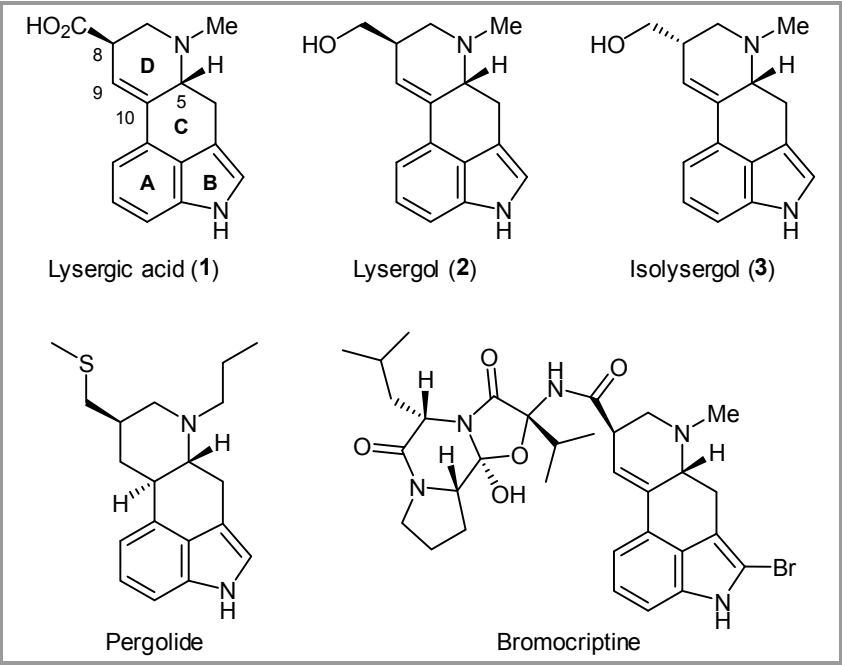

Figure 1 Indole alkaloids of the ergot family and their synthetic derivatives.

The ergot family of alkaloids consists of several pharmacologically important fused indoles, including lysergic acid (1), lysergol (2), and isolysergol (3) (Figure 1). Compounds belonging to this particular family are produced by the fungus Claviceps purpurea, which grows parasitically on rye and other grains, ${ }^{2}$ and have been reported to possess a variety of different biological activities. For example, pergolide and bromocriptine, which are synthetic derivatives of the ergot alkaloids, are clinically used as anti-prolactin and anti-Parkinson's disease drugs, respectively. ${ }^{3}$ Lysergic acid diethylamide (LSD) is well known as a strong psychoactive agent. The characteristic 
structural feature of these alkaloids is their tetracyclic fused indole, which contains a $\Delta^{9,10}$-double bond and chiral centers at the $\mathrm{C} 5$ and $\mathrm{C} 8$ positions.

Ergot alkaloids, especially lysergic acid, have been the target of many synthetic studies because of their biological importance as well as their structural complexity. The first total synthesis of racemic lysergic acid was accomplished by Woodward in $1956 .^{4 a}$ Several racemic syntheses of ergot alkaloids have subsequently been reported, ${ }^{4,5}$ with most of the strategies involving the stepwise and linear construction of the $\mathrm{C} / \mathrm{D}$ ring system. One important exception, however, is the strategy described by Oppolzer, ${ }^{4 d}$ which involved the simultaneous construction of the $\mathrm{C} / \mathrm{D}$ rings through an intramolecular imino-Diels-Alder reaction. The asymmetric total synthesis of lysergic acid was first reported in 2004 by Szántay and coworkers, ${ }^{6 a}$ which involved the resolution of a racemic tetracyclic intermediate using dibenzoyl-L-tartaric acid. In 2009, Fukuyama et al. reported the asymmetric synthesis of the methyl ester of lysergic acid using a Heck cyclization reaction $^{6 \mathrm{~b}}$ or palladium-catalyzed doublecyclization ( $\mathrm{N}$-arylation and Heck reaction). ${ }^{6 c}$ More recently, $\mathrm{Jia}^{6 \mathrm{e}}$ reported the asymmetric total synthesis of lysergic acid using a RCM reaction as the key step. This particular report was published after our own report (vide infra) ${ }^{6 \mathrm{~d}}$

Based on our recent studies towards palladiumcatalyzed cascade cyclization reactions, we designed a novel strategy for the construction of the core structure of ergot alkaloids that could be used for the asymmetric total synthesis of lysergic acid (1), lysergol (2), and isolysergol (3).

\subsection{Construction of the Core Structure of the Ergot Alkaloids using a Palladium- Catalyzed Cascade Cyclization ${ }^{4 \mathrm{j}}$}

It is well known that arylpalladium halides generated in situ from the reaction of aryl halides with palladium $(0)$, can regioselectively react with allenes to form $\eta^{3}$-allylpalladium(II) intermediates (Scheme 1) ${ }^{7,8}$ In 2003 , we reported the direct formation of the tricyclic isoindole derivatives $\mathbf{5}$ from allenes $\mathbf{4}$ using an alkene carbopalladation reaction followed by a direct arylation/C-H bond functionalization (7 to 8) (Scheme 2). ${ }^{9}$ The reaction of $\mathbf{4}$ with heterocyclic aryl halides provided direct access to the corresponding triand tetracyclic heteroaromatic products. More recently, we reported a fully intramolecular cascade cyclization reaction using amino allene derivatives, ${ }^{10}$ with similar results also being reported by some other groups. ${ }^{11,12}$ For example, the reaction of 9 under these conditions terminates with the nucleophilic attack of a protected amino group to afford $\mathbf{1 0}$ (Scheme 3 ). ${ }^{10}$

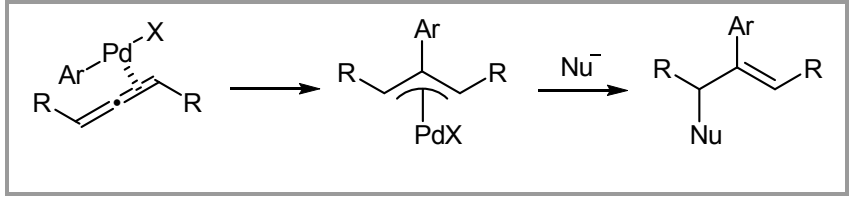

Scheme 1 General Scheme for Palladium-Catalyzed Reaction of Allenes with Aryl Halides and Nucleophiles

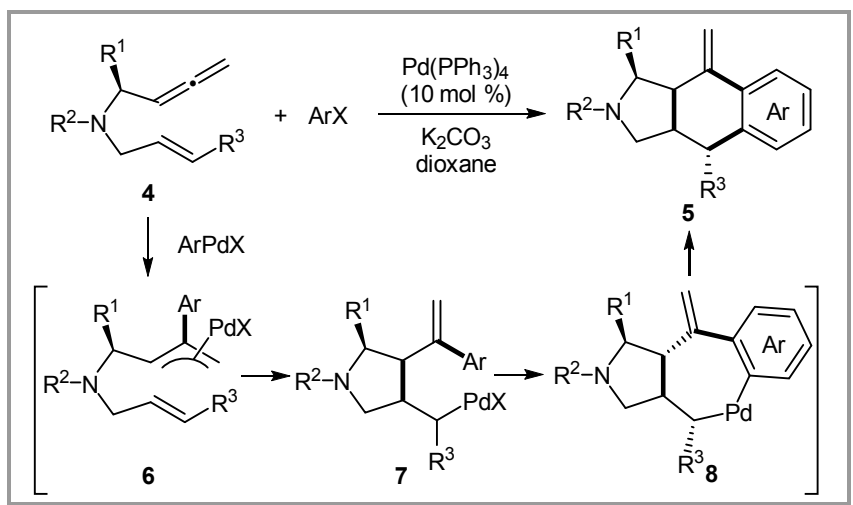

Scheme 2 Palladium-Catalyzed Cascade Cyclization of Allenene Derivatives with an Aryl Halide.

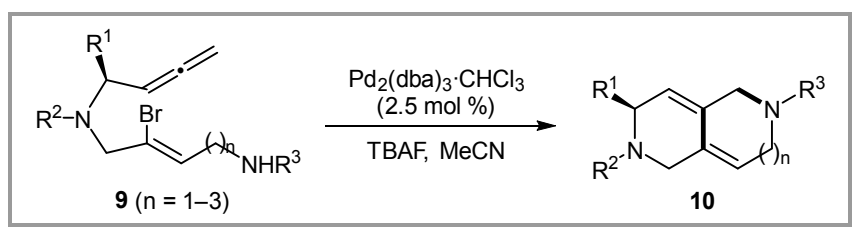

Scheme 3 Palladium-Catalyzed Fully Intramolecular Cascade Cyclization of Amino Allene Derivatives.

In light of this chemistry, it was envisaged that the palladium-catalyzed cascade cyclization of amino allenes 12 bearing a protected 4-bromoindol-3-yl group (Scheme 4) would provide direct access to tetracyclic indoles $\mathbf{1 1}$ bearing the core structure of the ergot alkaloids. The development of such a strategy for the construction of the desired 6,6-fused C/D ring system would be challenging, because the reaction of an internal allene bearing an aryl halide and amino group at both ends was unprecedented. ${ }^{10-12}$ The allene unit of $\mathbf{1 2}$ could be constructed via the Claisen rearrangement of the propargyl enol ether 13, which could be readily obtained through the conjugate addition of propargyl alcohol $\mathbf{1 4}$ to methyl propiolate. 


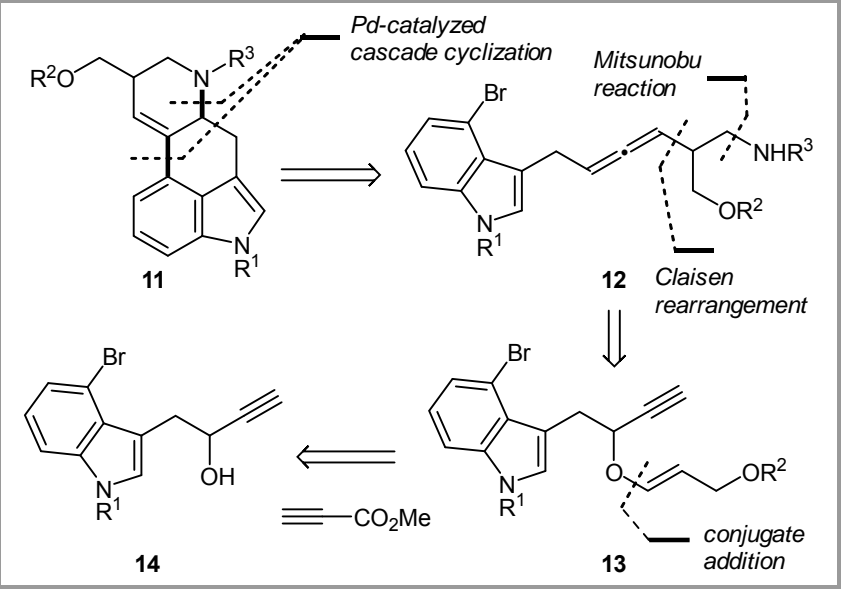

Scheme 4 Retrosynthetic Analysis of the Racemic Cyclization Precursor 12.

Racemic allenic amide 19 was prepared as a model compound to evaluate the overall scope of our strategy for the construction of the core structure of ergot alkaloids (Scheme 5). Commercially available 4bromoindole (15) was readily converted to the protected 3-(bromomethyl)indole (16) via the formylation of the indole at the 3-position, followed by sequential $N$-tosylation, reduction of the 3 -formyl group, and the bromination of the resulting primary hydroxy group. The addition of lithiated 1,3-dithiane ${ }^{13}$ to $\mathbf{1 6}$, followed by hydrolysis of the thiacetal, ${ }^{14}$ and subsequent reduction of the resulting ketone gave racemic propargyl alcohol 17. The propargyl vinyl ether $\mathbf{1 8}$ was then obtained via the conjugate addition of $\mathbf{1 7}$ to methyl propiolate, ${ }^{15}$ followed by sequential DIBAL reduction of the resulting enolate and TIPS protection of the resulting alcohol. The Claisen rearrangement of 18 under thermal conditions ( $m$ xylene, $170^{\circ} \mathrm{C}$ ) did not proceed as anticipated and gave the desired allenic alcohol $(\mathrm{dr}=c a .33: 67)$ in a low yield of only $38 \%$. Pleasingly, however, the use of $5 \mathrm{~mol} \%$ of the gold-oxo complex $\left[\left(\mathrm{Ph}_{3} \mathrm{PAu}\right)_{3} \mathrm{O}\right] \mathrm{BF}_{4}{ }^{16}$ gave the rearrangement product in $78 \%$ yield following the reduction of the aldehyde with $\mathrm{NaBH}_{4}$ $(\mathrm{dr}=c a$. 80:20, favoring the opposite diastereomer to the thermal conditions). A Mitsunobu reaction with $\mathrm{NsNH}_{2}$ gave the allenic nosylamide derivative 19 as a mixture of diastereomers $(\mathrm{dr}=80: 20)$, which was progressed directly into the subsequent step without separation. The corresponding tosylamide derivative $20(\mathrm{dr}=c a .80: 20)($ Scheme 6) was also prepared in a similar manner using TsNHFmoc in the Mitsunobu reaction. ${ }^{17}$

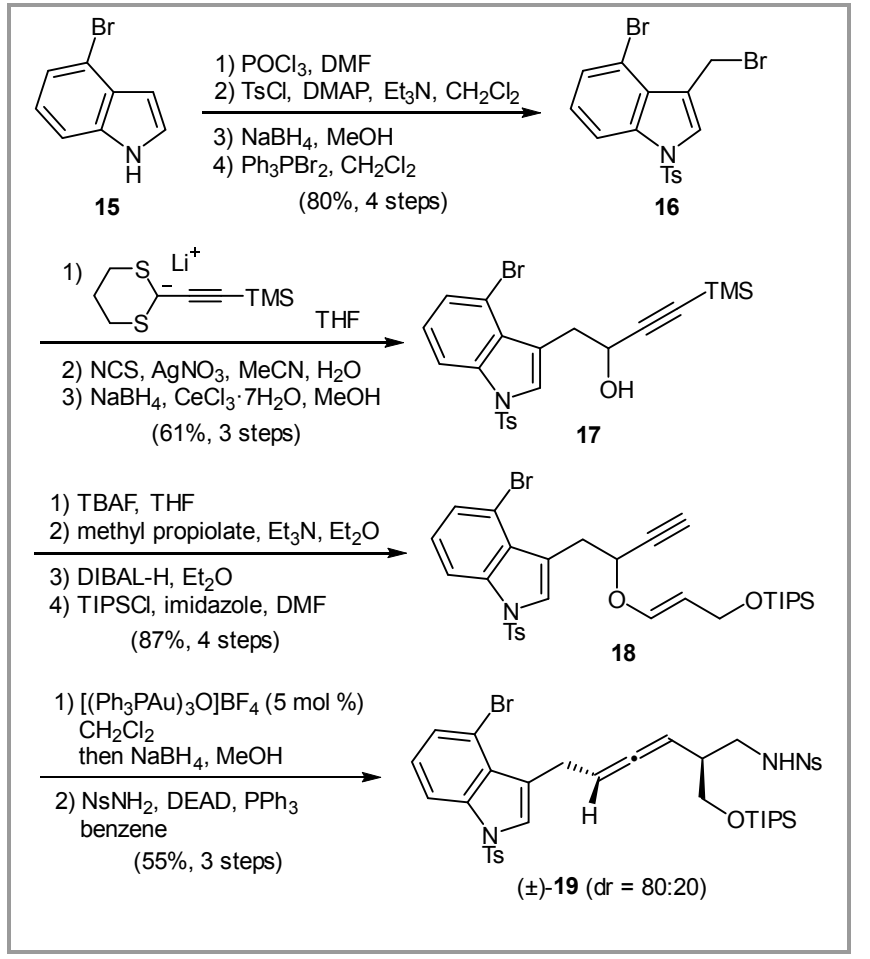

Scheme 5 Synthesis of the Racemic Cyclization Precursor 19 by a Gold-Catalyzed Claisen Rearrangement

We then proceeded to investigate the construction of the ergot alkaloid skeleton using the palladiumcatalyzed cascade cyclization (Scheme 6). Among the different palladium catalysts $\left[\mathrm{Pd}(\mathrm{OAc})_{2} / \mathrm{PPh}_{3}\right.$, $\mathrm{PdCl}_{2}$ (dppf), $\mathrm{Pd}(\mathrm{OAc})_{2} / \mathrm{P}(o-\text { tol })_{3}$ and $\mathrm{Pd}(\mathrm{OAc})_{2} /$ racBINAP], bases $\left(\mathrm{Na}_{2} \mathrm{CO}_{3}, \mathrm{Cs}_{2} \mathrm{CO}_{3}\right.$, and $\left.\mathrm{K}_{2} \mathrm{CO}_{3}\right)$, and solvents (DMF, DMSO, toluene, and dioxane) tested, a combination of $5 \mathrm{~mol} \%$ of $\mathrm{Pd}\left(\mathrm{PPh}_{3}\right)_{4}$ with $\mathrm{K}_{2} \mathrm{CO}_{3}$ in DMF was found to be the most effective, and gave the desired tetracyclic indole 21 in $83 \%$ yield as a 73:27 stereoisomeric mixture. When the $N$-tosyl derivative 20 was subjected to the optimized reaction conditions, the desired product 22 was isolated in $65 \%$ yield with good diastereoselectivity $(87: 13)$. The decision was taken to use the tosylamide as the cyclization precursor for our asymmetric total syntheses in the current study because of the stereoselectivity and ease of deprotection that this group offered (Section 2.2). 


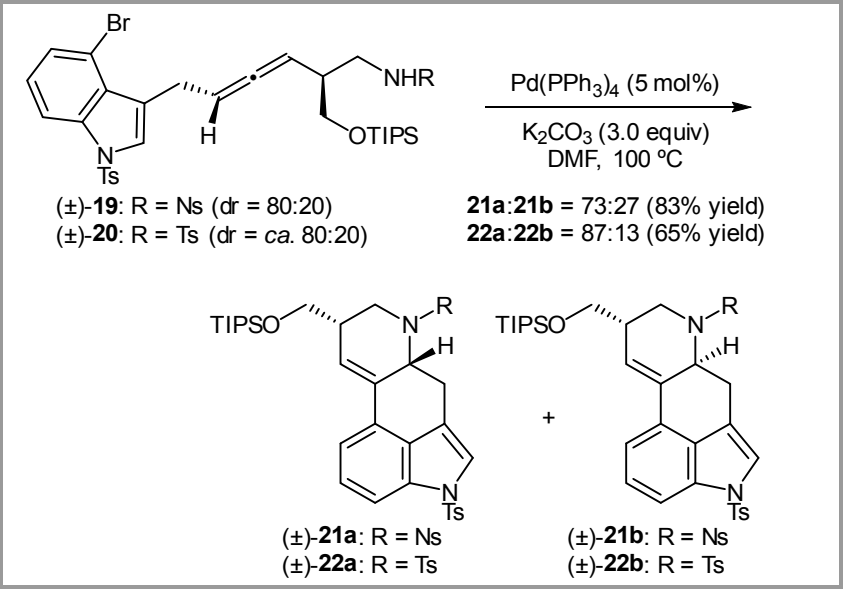

Scheme 6 Construction of the Ergot Alkaloid Core Structure Using the Palladium-Catalyzed Cascade Cyclization

The different diastereomers of the allene were carefully separated by HPLC and subjected to the cascade cyclization conditions to develop a deeper understanding of the reaction mechanism (Scheme 7). The major isomer 19a gave an 83:17 mixture of isomers in 78\% yield, with 21a being isolated as the major cyclized product, as anticipated. In contrast, the minor isomer 19b gave the other diastereomer $\mathbf{2 1 b}$ $(\mathbf{a}: \mathbf{b}=21: 79)$ as the major product in a combined yield of $67 \%$ yield. These results can be understood in terms of the aminopalladation pathway, as discussed below.

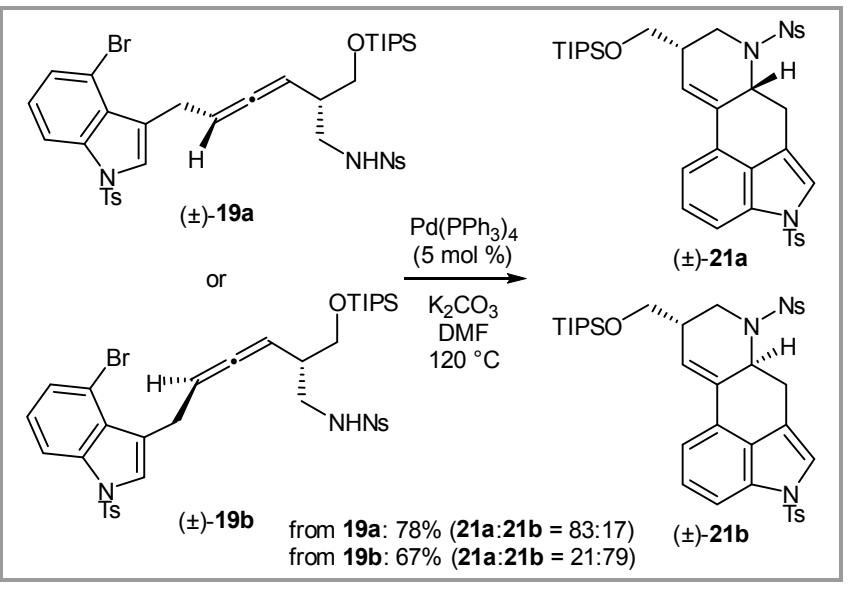

Scheme 7 The Cascade Cyclization of Each Diastereomer

It can be difficult to predict the product distribution of the palladium-catalyzed cyclization of amino allenes with an aryl halide, ${ }^{18}$ because reactions of this type can proceed via the two competing major pathways, including (a) the aminopalladation ${ }^{19}$ and (b) carbopalladation $^{20}$ pathways (Scheme 8). In the aminopalladation pathway, the arylpalladium halide activates the distal double bond of the amino allene $\mathbf{2 3}$ from the least hindered side and promotes an endotype cyclization (eq 1), with nitrogen heterocycle 25a being formed stereospecifically via a reductive elimination step. The occurrence of an aminopalladation reaction at the proximal double bond would give its regioisomer 27 (eq 2). In contrast, carbopalladation onto the distal double bond from the least hindered side of the double bond would give the $\eta^{1}$-allylpalladium(II) intermediate $\mathbf{2 8}$, which would lead to the $\eta^{3}$-intermediates 29a and 29b through isomerization. Subsequent intramolecular anticyclization would then give the endo-cyclization product 25a (eq 3 ) and/or the exo-cyclization product 27 (eq 4). These are the same products as those formed from the distal and proximal bond aminopalladation pathways (eqs 1 and 2). It is noteworthy that the cyclization product $\mathbf{2 5} \mathbf{b}$, formed through a carbopalladation at the proximal double bond followed by an endo-cyclization (eq 5), has the opposite configuration to the distal aminopalladation product 25a (eq 1). The exo-type cyclization product 27 could also be formed from the $\eta^{3}$-allylpalladium intermediates 29d (eq 6), which makes it particularly difficult to predict the outcome of reactions of this type.
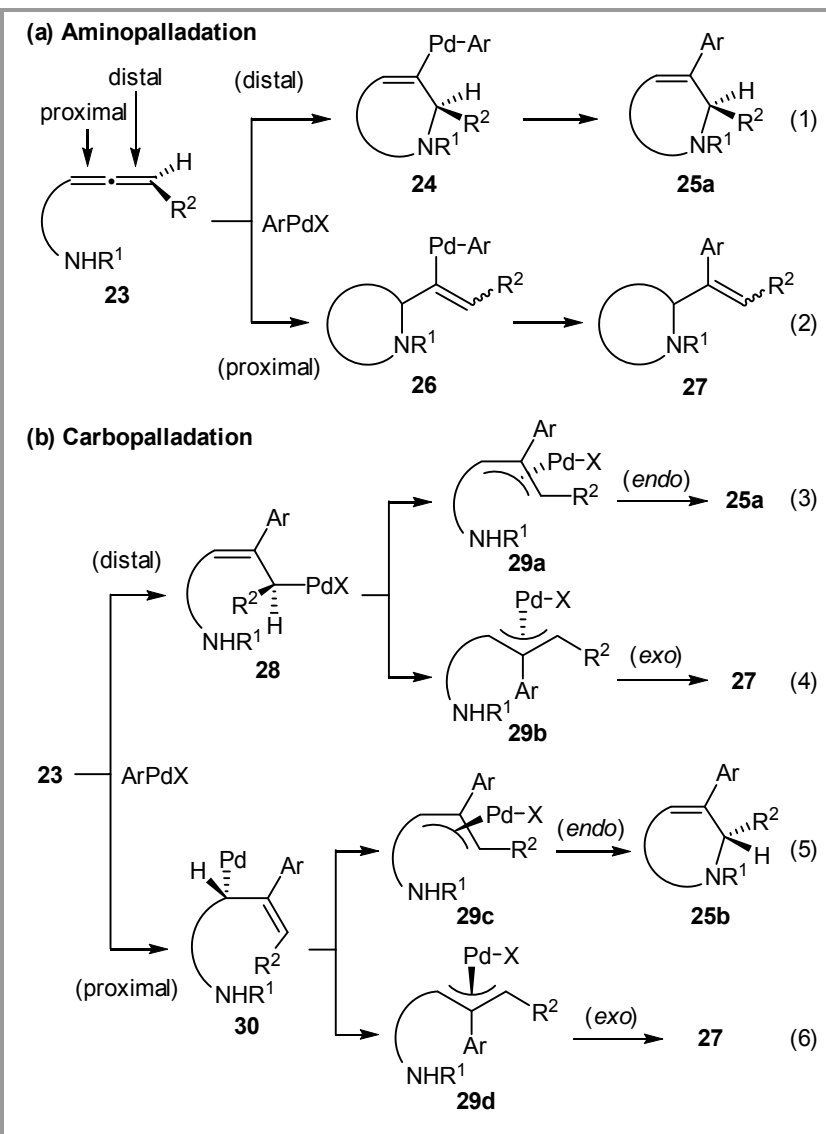

Scheme 8 General Reaction Pathways for the Palladium-Catalyzed Reaction of Amino Allenes with Arylpalladium Halides

In our case, aminopalladation at the distal double bond (as in eq 1 of Scheme 8 to form 25a) adequately explains the formation of the major isomer 21a from the amino allene 19a (Scheme 9). Coordination of the indolylpalladium(II) to the allenic moiety would promote anti-attack of the sulfonamide group as shown in 31. Aminopalladation from the favored 
conformation would generate the seven-membered palladacycle 32, and subsequent reductive elimination would give the major isomer 21a. In contrast, carbopalladation at the proximal double bond (as in eq 5 of Scheme 8 to form $25 \mathbf{b}$ ) would rationalize the formation of the minor isomer $\mathbf{2 1 b}$, with a steric effect in the carbopalladation of indolylpalladium(II) bromide allowing for the carbopalladation to proceed onto the proximal double bond, as depicted in $\mathbf{3 3}$, to generate the $\eta^{3}$-allylpalladium complex 34 . The second cyclization resulting from the sulfonamide group would then occur in an anti-manner to give the minor isomer $\mathbf{2 1 b}$. The formation of $\mathbf{2 1 a}$ as the major product can be explained in terms of the strained bicyclic structure $\mathbf{3 3}$ in the carbopalladation step

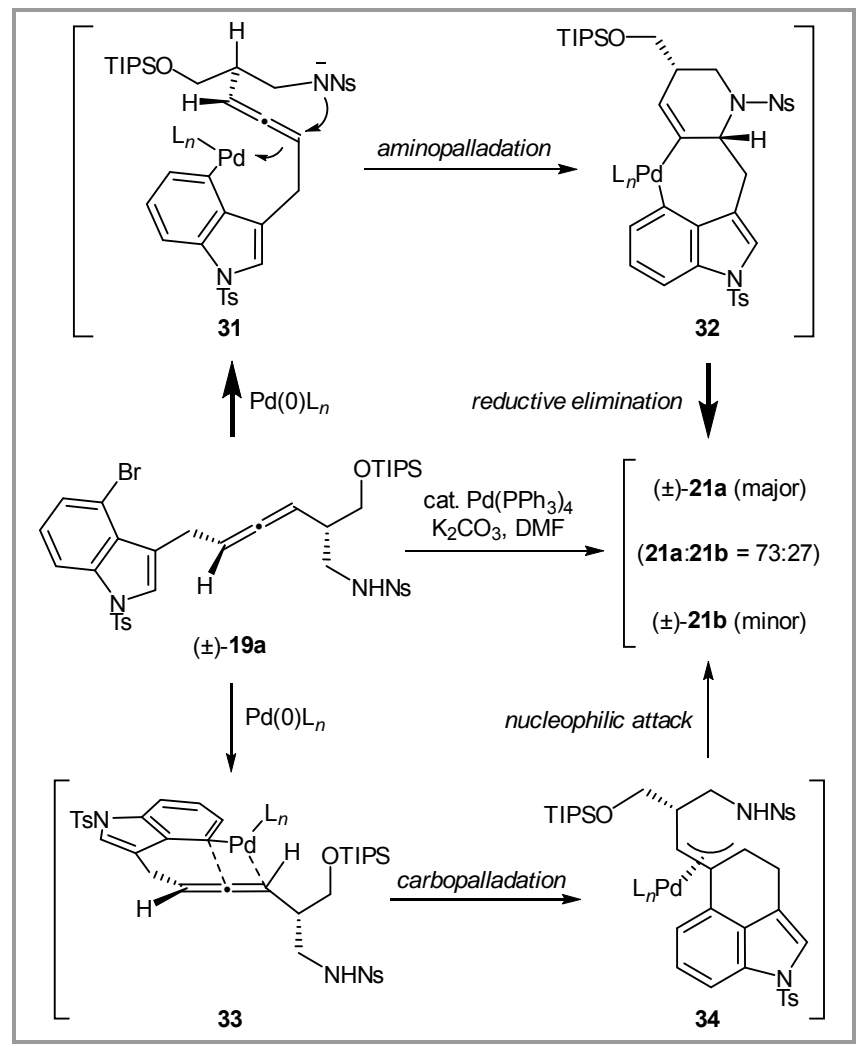

Scheme 9 Possible Pathways to 21a and 21b via Aminopalladation and Carbopalladation

\subsection{Asymmetric Total Synthesis of (+)- Lysergic Acid and Related Alkaloids ${ }^{6 \mathrm{~d}}$}

We then proceeded to investigate the asymmetric total synthesis of ergot alkaloids using the established cascade cyclization conditions for the construction of their core structure. In light of the difficulties that we experienced controlling the stereoselectivity of the Claisen rearrangement of propargyl enol ether $\mathbf{1 8}$ (Scheme 5), we made changes to the synthetic route used to access the amino allene. As shown in Scheme 10 , it was envisaged that the chiral allene unit of $\mathbf{3 5 a}$ could be constructed from enantiomerically enriched propargyl alcohol 36a using the method reported by Myers. ${ }^{21}$ The propargyl alcohol 36a could be obtained from the coupling of aldehyde $\mathbf{3 7}$ with alkynes $\mathbf{3 8}$. If necessary, oxidation and asymmetric hydrogenation reactions could be used for asymmetric induction at the propargyl position. The alkynes $\mathbf{3 8}$ could be accessed from the known 2-ethynylaziridine $39,{ }^{22}$ which can be derived from L-serine via an indium(I)mediated reductive coupling reaction with formaldehyde, which was developed by our group. ${ }^{23}$

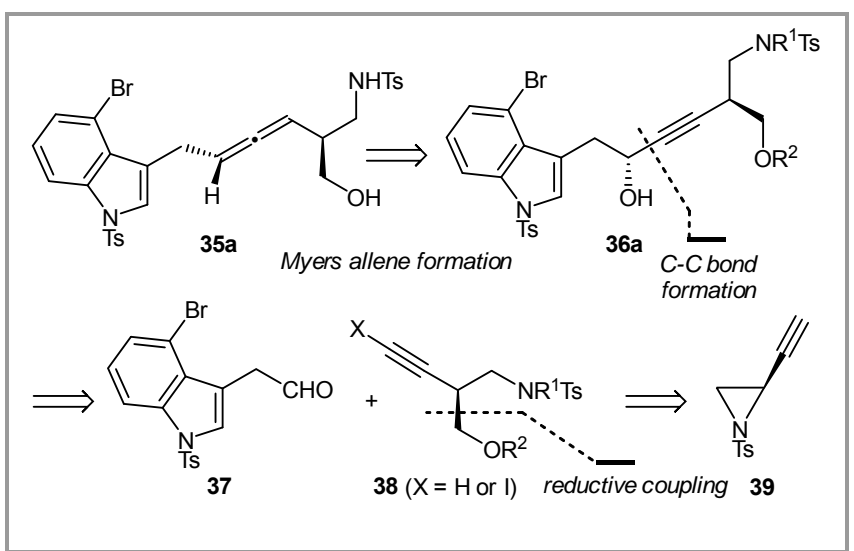

Scheme 10 Retrosynthetic Analysis of Enantiomerically Enriched Cyclization Precursor 35a

The synthesis of the alkynes $\mathbf{3 8}$ is shown in Scheme 11. Following our reported procedure, ${ }^{22}$ the enantiomerically enriched aziridine 39 (97\% ee) was prepared from (S)-Garner's aldehyde ${ }^{24}$ via sequential alkyne formation, deprotection, $N$-tosylation, and aziridine formation reactions. Treatment of the aziridine 39 with formalin under the InI-mediated reductive coupling condition [i.e., $\mathrm{Pd}\left(\mathrm{PPh}_{3}\right)_{4}$ (5 mol \%), InI, THF/HMPA (4:1) $]^{23}$ gave the desired 1,3amino alcohol 38a $(97 \%$ ee) in $88 \%$ yield. A single recrystallization afforded optically pure $\mathbf{3 8 a}(99 \%$ ee). The benzylidene acetal $\mathbf{3 8 b}$ and the corresponding iodoalkyne derivative 38c were prepared by the treatment of 38a with benzaldehyde dimethylacetal/CSA (followed by $\mathrm{NIS} / \mathrm{AgNO}_{3}{ }^{25}$ for 38c).

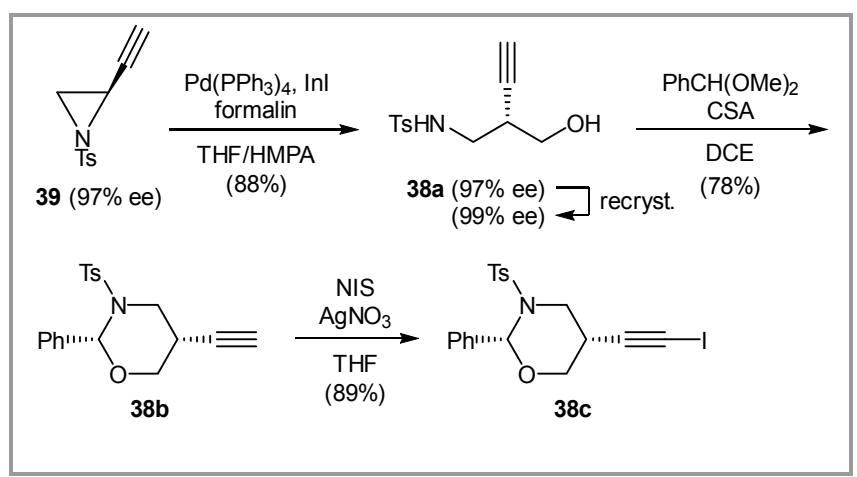

Scheme 11 Preparation of the Alkyne Units 38. DCE $=1,2$ dichloroethane

We next investigated the preparation of aldehyde $\mathbf{3 7}$ and its cross-coupling reaction with the alkynes $\mathbf{3 8}$ 
(Scheme 12). Commercially available 4-bromoindole 40 was converted to 3-allylindole 41 using a palladium-catalyzed $\mathrm{C} 3$-selective allylation reaction with allyl alcohol and triethylborane, ${ }^{26}$ followed by $\mathrm{N}$ protection. $\mathrm{OsO}_{4} / \mathrm{NaIO}_{4}$-mediated oxidation of $\mathbf{4 1}$ gave the desired aldehyde 37. Among the different methods available for the coupling of $\mathbf{3 7}$ and $\mathbf{3 8}$, including $n$-BuLi, $n$-BuLi/ $\mathrm{CeCl}_{3},{ }^{27} \quad \mathrm{InBr}_{3} /(R)$ BINOL ${ }^{28}$ and $\mathrm{Et}_{2} \mathrm{Zn} /(\mathrm{S})-\mathrm{BINOL} / \mathrm{Ti}(\mathrm{O} i-\mathrm{Pr}){ }_{4},{ }^{29}$ the $\mathrm{Cr}(\mathrm{II}) / \mathrm{Ni}(0)-$ mediated Nozaki-Hiyama-Kishi (NHK) reaction $^{30}$ using iodoalkyne 38c was found to be the most efficient procedure, resulting in formation of the desired coupling product in $90 \%$ yield $(\mathrm{dr}=1: 1)$. Unfortunately, subsequent attempts to carry out the asymmetric NHK reaction ${ }^{31}$ failed to produce the desired propargyl alcohol, and an isomeric mixture of the propargyl alcohol was therefore oxidized to $\mathbf{4 2}$ and subjected to an $(R)$-Alpine-borane-mediated asymmetric reduction $^{32}$ to afford the propargyl alcohol 36a with high diastereoselectivity $(\mathrm{dr}=>95: 5)$. Finally, the allenic amide 35a was obtained from 36a according to the method reported by Myers, ${ }^{21}$ with nosyl hydrazine being used under Mitsunobu conditions followed by the cleavage of the benzylidene group. The diastereomeric allenic amide 35b (Scheme 13) was prepared in a similar manner via the reduction of ketone $\mathbf{4 2}$ with $(S)$-Alpine-borane.

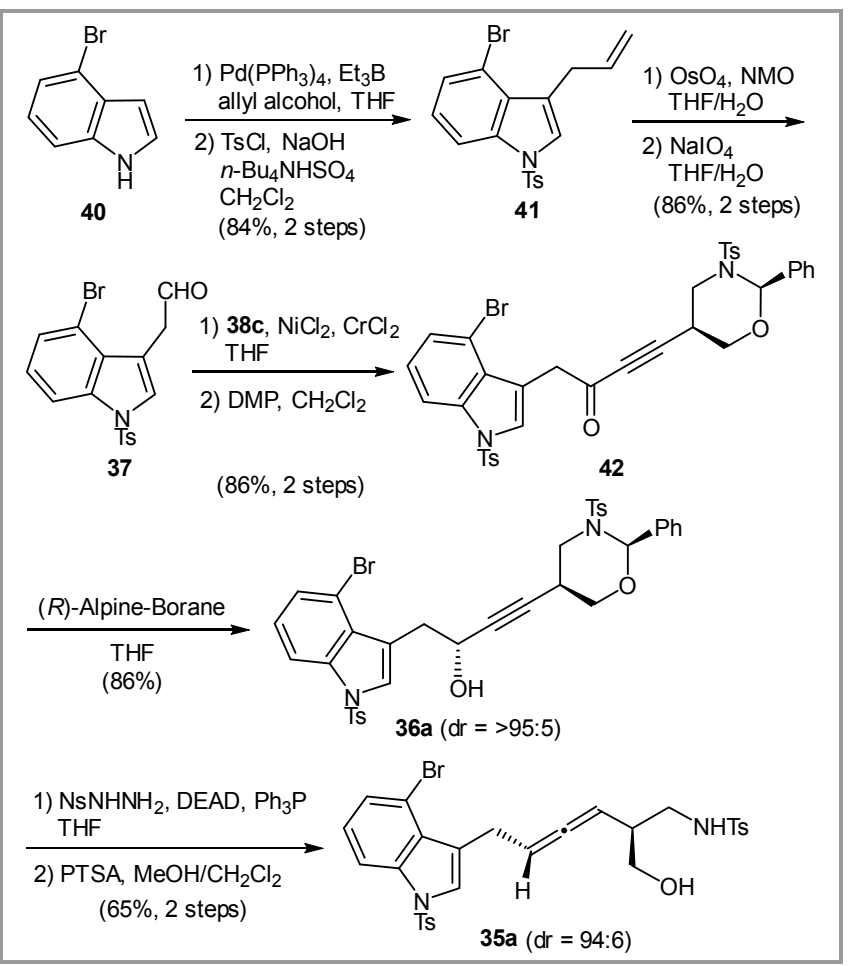

Scheme 12 Stereoselective Synthesis of the Enantiomerically Enriched Cyclization Precursor 35a. DMP = Dess-Martin periodinane.

The construction of the ergot alkaloid skeleton via the palladium-catalyzed cascade cyclization of the allenic amides 35 bearing a free hydroxy group is shown in Scheme 13. The reaction of 35a (94:6 isomeric mixture) under the optimized conditions, which were developed above for the cascade cyclization of the racemic model substrates 19 and 20 bearing a silyl ether moiety (Scheme 6), provided the desired product 43 in $76 \%$ yield. The diastereomeric allenic amide 35b afforded the cyclization products $43 \mathrm{a}$ and $\mathbf{4 3 b}$, although the reaction was not as efficient or stereoselective $(43 \%$ yield, $43 \mathbf{a}: 43 \mathbf{b}=31: 69)$. Once again, these results reveal the differences in the reactivity of the diastereomeric substrates.

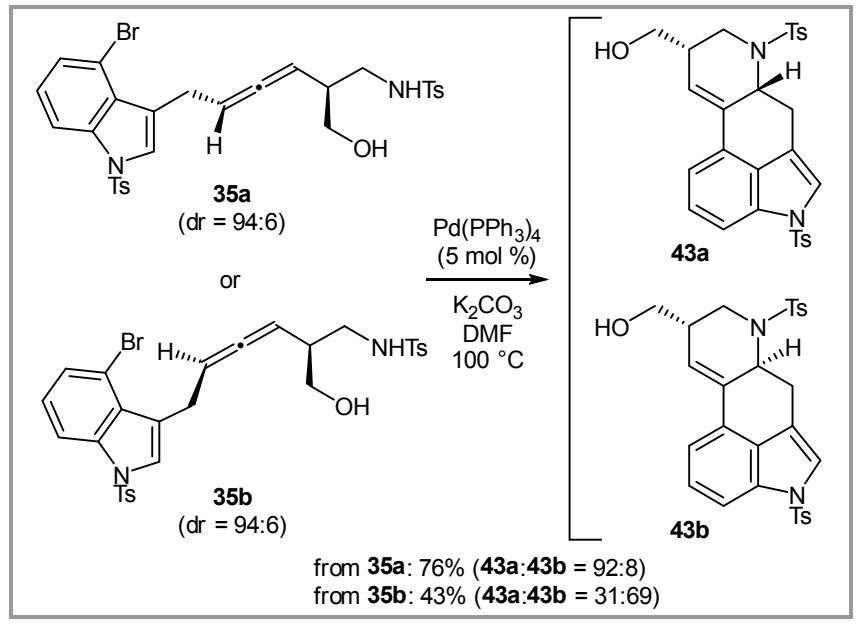

Scheme 13 Cascade Cyclization of $\mathbf{3 5}$

With the tetracyclic indole 43a in hand with all of the requisite functionalities, we proceeded to investigate the total synthesis of the ergot alkaloids. A simple two-step procedure for the conversion of 43a to isolysergol (3) is shown in Scheme 14. Removal of the tosyl groups of $43 a$ with sodium naphthalenide and subsequent $N$-methylation followed by separation of the diastereomers gave (+)-isolysergol (3) in $46 \%$ yield (99\% ee, Chiralcel OD-H).

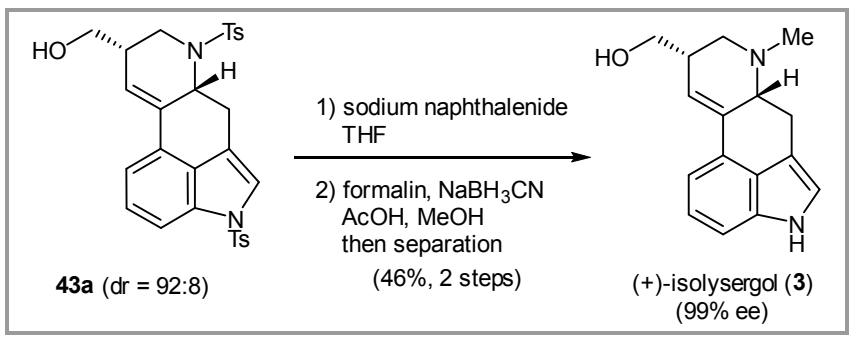

Scheme 14 Total Synthesis of (+)-Isolysergol (3)

The syntheses of lysergic acid and lysergol from 43a would require the inversion of the stereochemistry at the 8-position, and this was accomplished by the epimerization of the corresponding ester derivatives (Scheme 15). Thus, the two-step oxidation of the primary alcohol in 43a followed by esterification with $\mathrm{TMSCHN}_{2}$ gave the corresponding methyl ester 44a (64\%, 3 steps). It was important to separate the diastereomers (derived from the chirality at the C-5 position) at this step for the preparation of lysergic 
acid (1) and lysergol (2) in high ee, because the successful conversion of 44a to $\mathbf{1}$ and $\mathbf{2}$ through isomerization would rely on the chiral information conveyed from the C-5 position. Cleavage of the two tosyl groups and subsequent reductive $N$-methylation led to a mixture of methyl isolysergate $\mathbf{4 5 a}$ and lysergate 45b $(65 \%$ yield, 45a:45b $=33: 67)$. Reduction of this mixture with $\mathrm{LiAlH}_{4}$ produced (+)lysergol (2) in 49\% yield (98\% ee, Chiralcel OD-H), together with (+)-isolysergol (3) (24\%). ${ }^{33}$ Finally, the lysergate $45(45 \mathbf{a}: 45 b=33: 67)$ was converted to $(+)-$ lysergic acid (1) in 54\% yield (96\% ee, Chiralcel OD$\mathrm{H}$ after methylation with $\left.\mathrm{TMSCHN}_{2}\right)^{34}$ by hydrolysis with $\mathrm{NaOH}$ with concomitant isomerization. ${ }^{6 a}$ All of the spectroscopic data collected for the synthesized compounds 1, 2, and $\mathbf{3}$ were in agreement with those of the natural and synthetic products reported in the literature. ${ }^{6,5 c}$

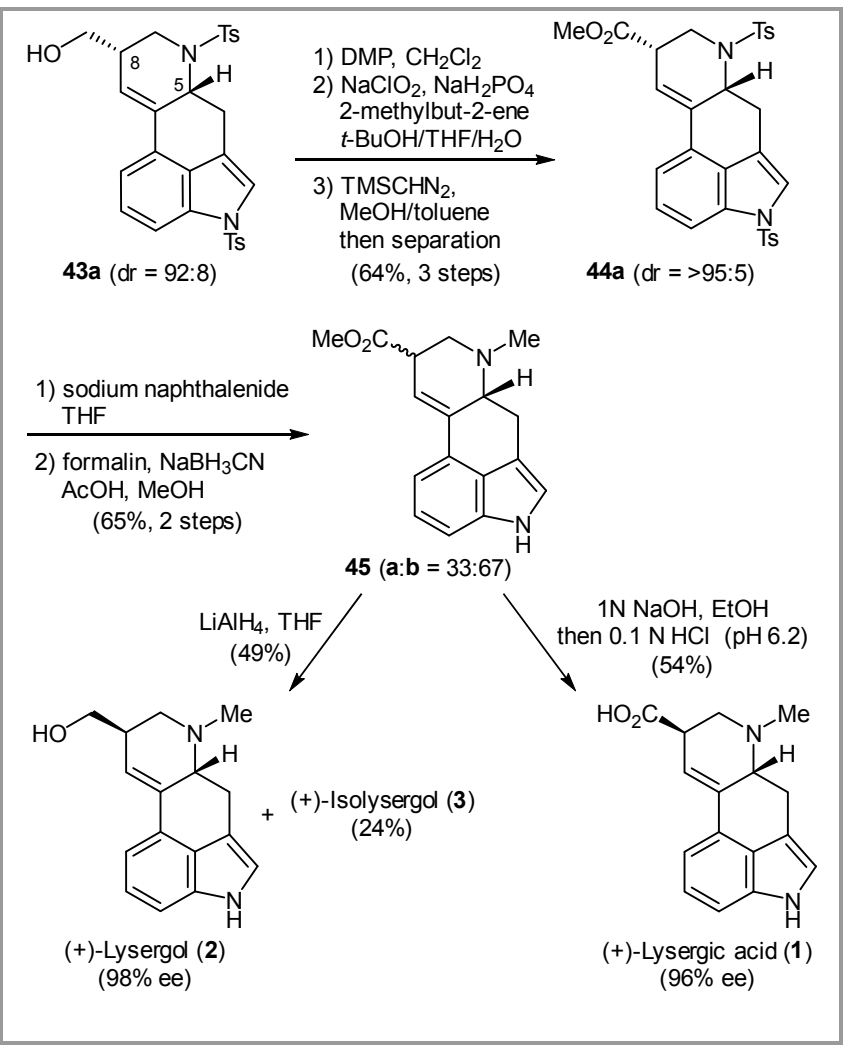

Scheme 15 Total Syntheses of (+)-Lysergic Acid (1) and (+)Lysergol (2)

\section{Quinocarcin Synthesis}

(-)-Quinocarcin (46), which was originally isolated from the culture of Streptomyces melanovinaceus, is a pentacyclic tetrahydroisoquinoline alkaloid with antiproliferative activity against lymphocytic leukemia (Figure 2). ${ }^{35}$ This particular compound is structurally similar to tetrazomine and lemonomycin, in that it shares a common skeleton composed of a piperizinohydro-isoquinoline motif. Saframycin and ecteinascidin 743 (Et-743, Yondelis ${ }^{\circledR}$ ) differ in terms of their D-ring, which is a six-membered ring. ${ }^{36}$ Some of these compounds have been report to display similar antitumor and antibiotic activities, with Et-743 in particular exhibiting high levels of activity towards a broad range of tumor cell lines at sub-nanomolar concentrations. ${ }^{37}$ The development of a divergent synthetic route to this class of compounds would therefore be of considerable value for drug discovery.

The potent biological properties and challenging molecular architectures of these compounds have led to the development of several different creative approaches for their total syntheses. ${ }^{36,38-40}$ Most of the methods reported in this area, however, were designed for the specific synthesis of one of these compounds, with the Pictet-Spengler condensation reaction being used in the majority of cases for the construction of the isoquinoline core structure. ${ }^{[38,39 e, f, 40]}$ In the interest of developing a novel, general and convergent strategy capable of providing access to several different tetrahydroisoquinolines, we designed a unique method for the construction of the core structure of the tetrahydroisoquinoline alkaloids core using a Sonogashira-coupling/alkyne hydroamination sequence.

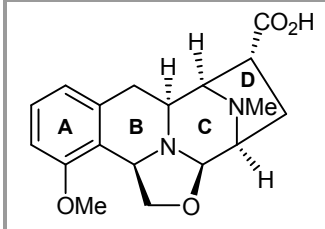

(-)-Quinocarcin (46)

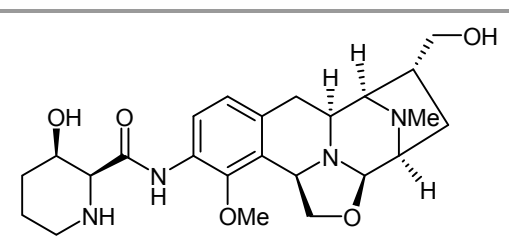

$(-)$-Tetrazomine

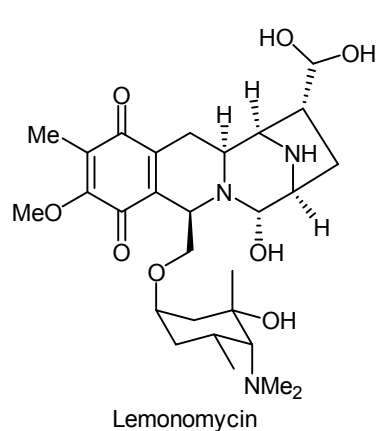

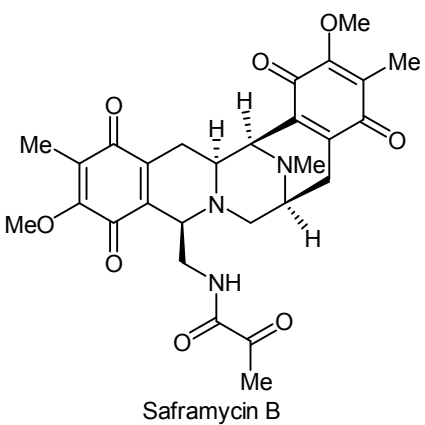

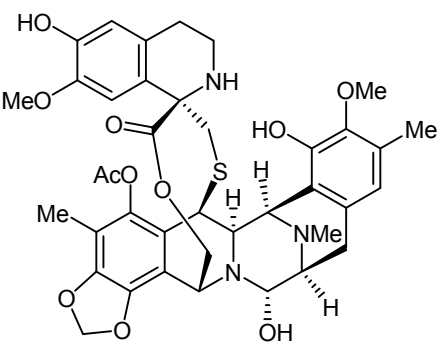

Ecteinascidin 743 (Et-743)
Figure 2 Quinocarcin and related tetrahydroisoquinoline alkaloids 


\subsection{Construction of the Core Structure by Gold-Catalyzed Hydroamination $^{39 \mathrm{~h}, \mathrm{i}}$ \\ Alkyne}

Intramolecular alkyne hydroamination catalyzed by a transition metal complex provides atom-economical and straightforward access to nitrogen-containing heterocycles. ${ }^{41}$ Recent progress in homogeneous gold catalysis has revealed that cationic gold complexes are extremely useful for alkyne hydroamination reactions, which can afford the desired addition products under mild reaction conditions. ${ }^{42}$

We recently reported the direct synthesis of 2(aminomethyl)indoles $\mathbf{4 8}$ and related compounds via a copper-catalyzed three-component Mannich-type coupling reaction between protected 2-ethynylanilines 47, aldehydes, and secondary amines followed by an intramolecular hydroamination (Scheme 16). ${ }^{43}$ The use of 2-ethynylbenzaldehyde $\mathbf{4 9}$ as a starting material under these conditions provided access to isoquinolines. ${ }^{44}$ We have also demonstrated that cationic gold catalysts promote the cascade cyclization of diynylaniline derivatives $\mathbf{5 1}$ to form fused carbazoles $\mathbf{5 2 .}{ }^{45,46}$ This transformation proceeded through an alkyne hydroamination reaction to form the indole ring followed by an alkyne hydroarylation.

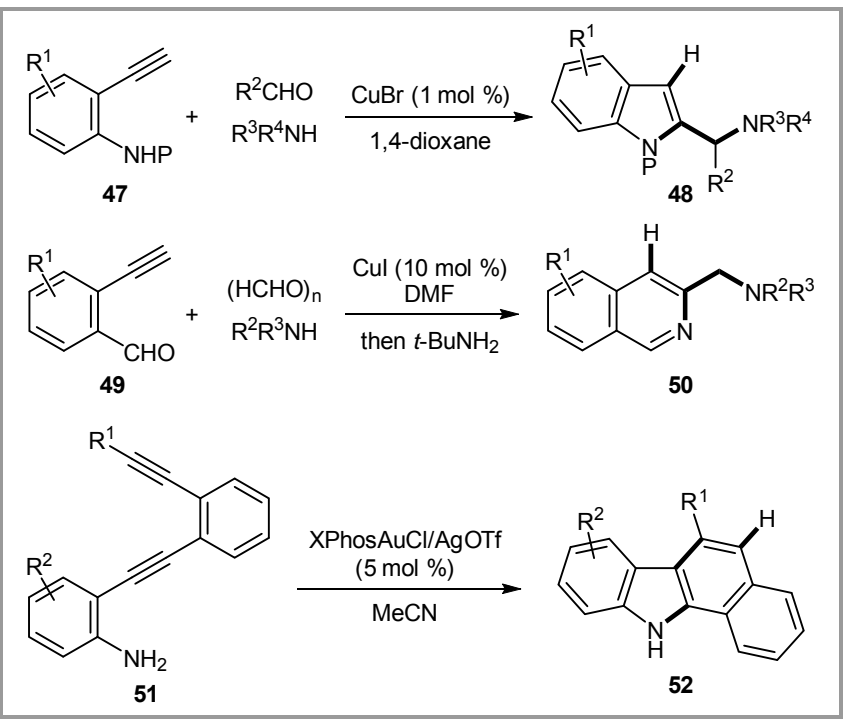

Scheme 16 Transition-Metal-Catalyzed Alkyne Hydroamination Reported by Our Group

Based on these studies, we design a novel a strategy aimed at providing access to the quinocarcin-type core structure through a transition-metal-catalyzed hydroamination. Our retrosynthetic analysis of (-)quinocarcin (46) is shown in Scheme 17. It was envisaged that quinocarcin could be obtained from lactam 53 following the procedures reported by $\mathrm{Zhu}^{39 f}$ and Stoltz. ${ }^{39 g}$ This lactam could be synthesized via the hydrogenation of enamine $\mathbf{5 4}$ followed by an intramolecular amide formation. The enamine $\mathbf{5 4}$ could be accessed according to the intramolecular hydroamination of alkyne 55, which could be readily prepared by the Sonogashira coupling reaction of the iodinated phenylglycinol derivative 56 and 2alkynylpyrrolidine 57. It was also envisaged that the bromoallene cyclization reaction previously reported by our group ${ }^{47}$ could be used for the stereocontrolled construction of the 2,5-cis-pyrrolidine 57. This synthetic strategy was particularly attractive because different quinocarcin derivatives and other related alkaloids could potentially be obtained by simply changing the coupling components 56 and 57 during the latter stages of the synthesis.
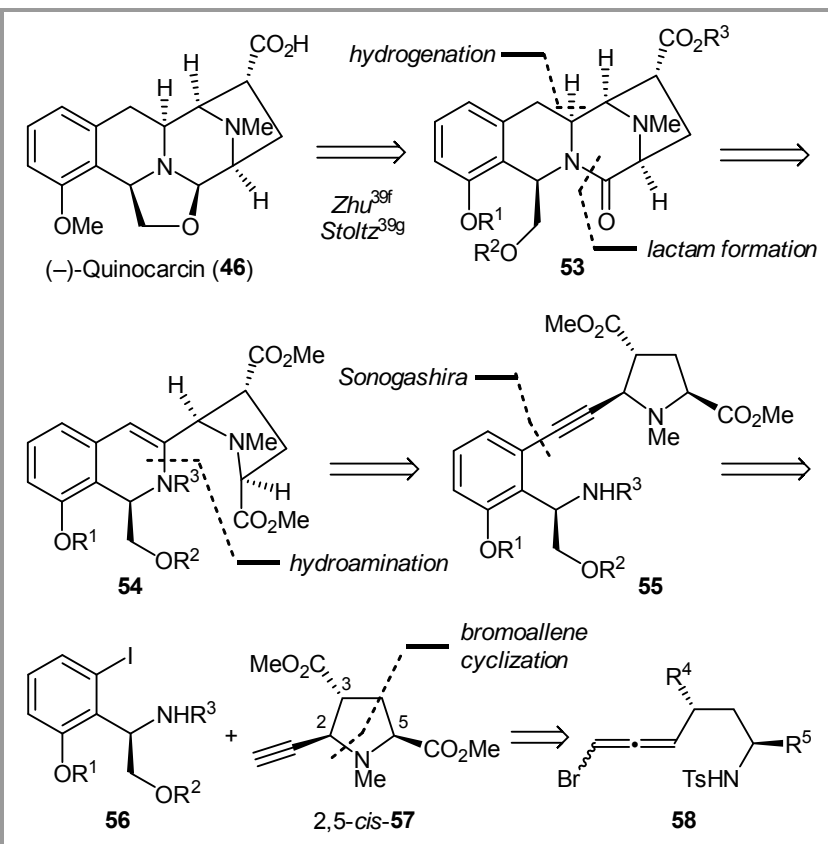

Scheme 17 Retrosynthetic Analysis of (-)-Quinocarcin

Control of the regioselectivity in the hydroamination of 55 would be critical to the success of this particular strategy. Thus, a 5-exo-dig cyclization would lead to the formation of the undesired isoindoline-type product 59 (Scheme 18), whereas a 6-endo-dig cyclization would afford the desired dihydroisoquinoline $\mathbf{5 4}$ required for the synthesis of quinocarcin. The 5-exo-dig cyclization could be predominated, however, because transition-metalcatalyzed $\mathrm{C}-\mathrm{N}$ bond formation reactions generally occur at the more cationic carbon atom of activated alkynes bearing an aryl substituent. With this in mind, our initial work involved the use of a model study to accomplish the 6-endo-dig cyclization. 


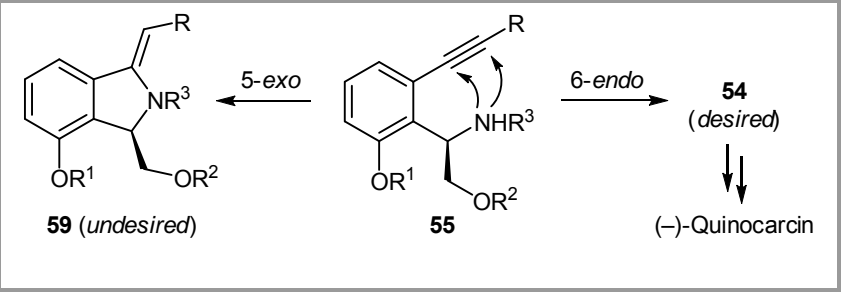

Scheme 18 Regioselectivity Issue in the Alkyne Hydroamination

The reaction of the model substrates $60 \mathbf{a}$, which was readily prepared by the Sonogashira coupling of the racemic an aryl iodide with a propargyl amine, is shown in Scheme 19. Disappointingly, the hydroamination of $60 \mathrm{a}$ using a variety of different transition-metal catalysts, including $\mathrm{Au}(\mathrm{I}), \mathrm{Cu}(\mathrm{I})$, $\mathrm{Pt}(\mathrm{II}), \mathrm{In}(\mathrm{III})$, and $\mathrm{Rh}(\mathrm{I})$ favored the 5-exo-dig cyclization in all cases to produce $\mathbf{6 2} \mathbf{a}$.

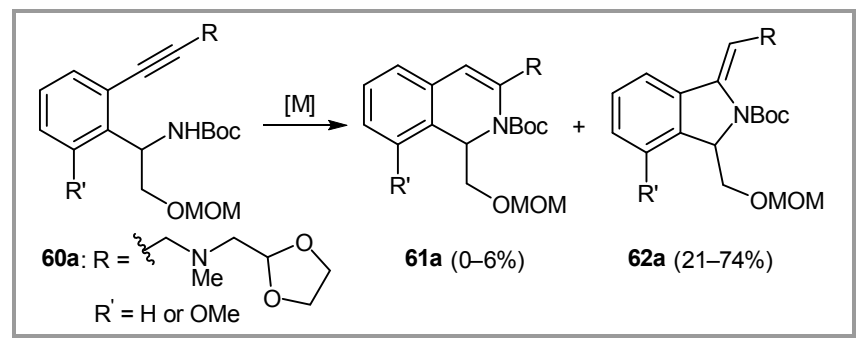

Scheme 19 Formation of the Undesired 5-exo-dig Cyclization Products

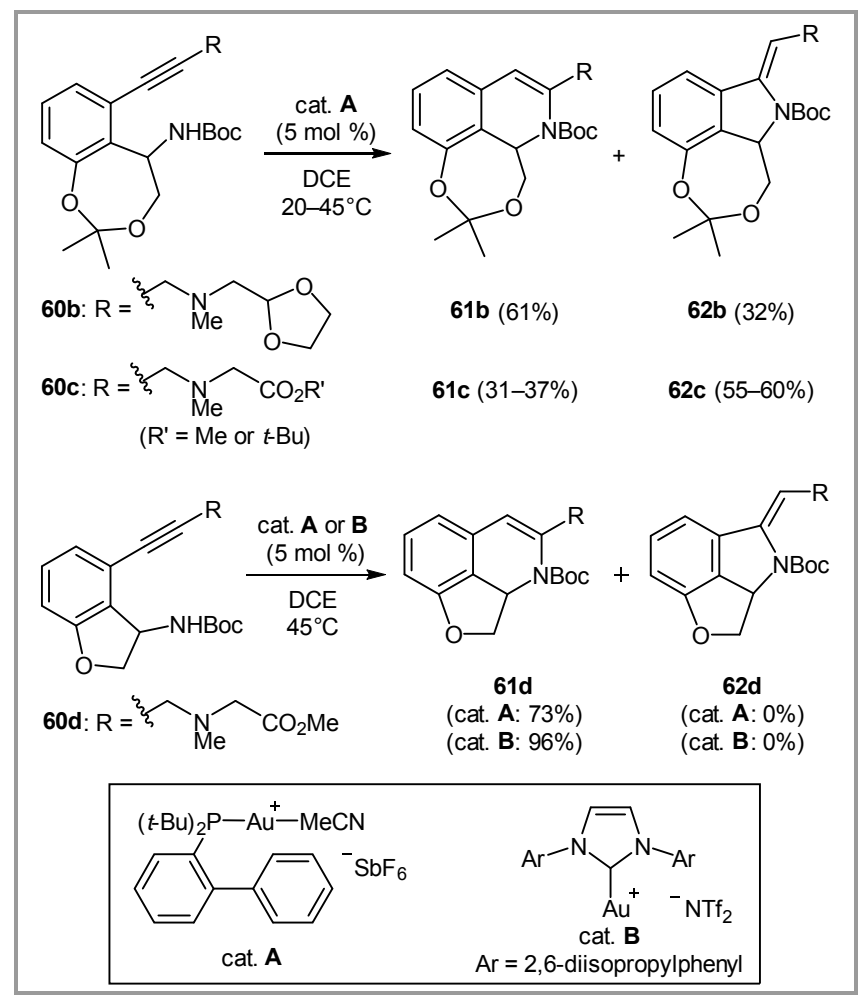

Scheme 20 Substrate-Controlled 6-endo-dig Hydroamination

The decision was then taken to modify the substrate structure (Scheme 20). Improvements in the regioselectivity were observed when the seven- membered acetonide-type substrates $60 \mathrm{~b}$ and 60c were treated with the gold catalyst $\mathbf{A}$, with the desired 6-endo-dig products $61 \mathrm{~b}(61 \%)$ and 61c $(31-37 \%)$, respectively, being isolated in moderate yields. It was envisaged that the destabilization of the 5-exo-dig product would lead to further improvements in the regioselectivity. With this in mind, we proceeded to examine the reaction of dihydrobenzofuran-type substrate 60d. In this particular case, the desired 6endo-dig product 61d was obtained exclusively in $73 \%$ yield. The gold catalyst $\mathbf{B}$ has proven to be highly active, affording 61d in 96\% yield. These model experiments therefore revealed that the phenylglycinol derivative 56 (Scheme 17) could be used as the target building block for the synthesis of quinocarcin as the corresponding dihydrobenzofurantype aryl iodide.

\subsection{Asymmetric Total Synthesis of (-)- Quinocarcin $^{39 h, i}$}

With an optimized procedure in hand for controlling the regioselectivity of the alkyne hydroamination reaction, we proceeded to investigate the preparation of the optically active dihydrobenzofuran $(R)-\mathbf{5 6 a}$ (Scheme 21). Formylation of 3-fluoroiodobenzene $\mathbf{6 3}$ with LDA and DMF followed by the Wittig reaction of the resulting aldehyde afforded the dihalostyrene 64 Subsequent Sharpless asymmetric dihydroxylation ${ }^{48}$ of 64 and a single recrystallization provided the optically pure diol $\mathbf{6 5}(>99 \%$ ee), which was converted to the desired dihydrobenzofuran derivative $(R)$-56a via the introduction of an azide group with DPPA under Mitsunobu conditions, ${ }^{49}$ followed by an intramolecular $\mathrm{S}_{\mathrm{N}} \mathrm{Ar}$ reaction to form the dihydrofuran ring using $t-\mathrm{BuOK}$, reduction of the azide group with $\mathrm{PhSH}, \mathrm{SnCl}_{2}$, and $\mathrm{Et}_{3} \mathrm{~N},{ }^{50}$ and Boc protection.

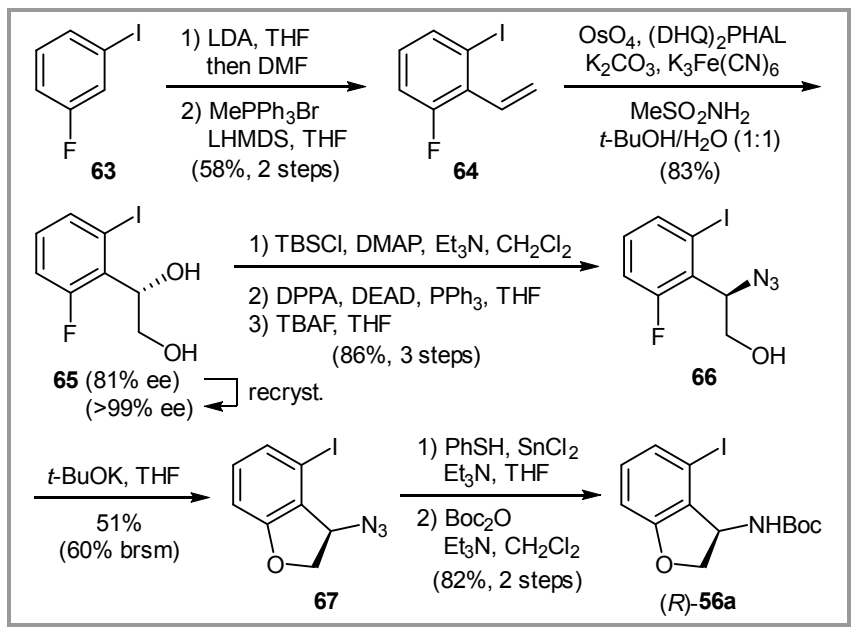

Scheme 21 Preparation of the Optically Active Dihydrobenzofuran $(R)$-56a. (DHQ) ${ }_{2} \mathrm{PHAL}=$ hydroquinine 1,4-phthalazinediyl diether; DPPA = diphenylphosphoryl azide.

The preparation of the 2,5-cis-pyrrolidine $\mathbf{5 7}$ using the bromoallene cyclization is shown in Scheme 22. The 
diastereoselective propargylation of $\gamma$-butyrolactone 68 gave the corresponding addition product 69 , which was reduced with $\mathrm{LiBH}_{4}$ followed by selective acetylation of the primary hydroxy group to give alcohol 70. Mitsunobu reaction with TsBocNH was then used to introduce the required nitrogen functionality, followed by selenium oxidation to give the propargyl alcohol $\mathbf{7 1}$ as a mixture of diastereomers. The bromoallene 58a $(\mathrm{dr}=55: 45)$ was then formed using a standard protocol involving the sequential mesylation and bromination reactions with $\mathrm{CuBr} \cdot \mathrm{SMe}_{2} / \mathrm{LiBr}^{51}$ As expected, the treatment of 58a with $\mathrm{NaH}$ in DMF led to a stereoselective pyrrolidine formation to afford the desired 2,5-cis-72 in 95\% yield (2,5-cis:trans $=96: 4)$. It is noteworthy that the intramolecular $\mathrm{S}_{\mathrm{N}} 2$ reaction using mesylate $\mathbf{7 4}$ derived from 71 under identical reaction conditions afforded 72 as a mixture of diastereomers (2,5-cis:trans $=$ $55: 45)$ in a ratio corresponding to that of the mesylate 74 (Scheme 23). Thus, the mesylate-to-bromoallene conversion is important in terms of controlling the 2,5-cis-selectivity. The desired pyrrolidine $\mathbf{5 7}$ for the Sonogashira coupling was then prepared from 2,5-cis72 according to sequential oxidation, esterification, and $\mathrm{N}$-methylation reactions using standard protocols.

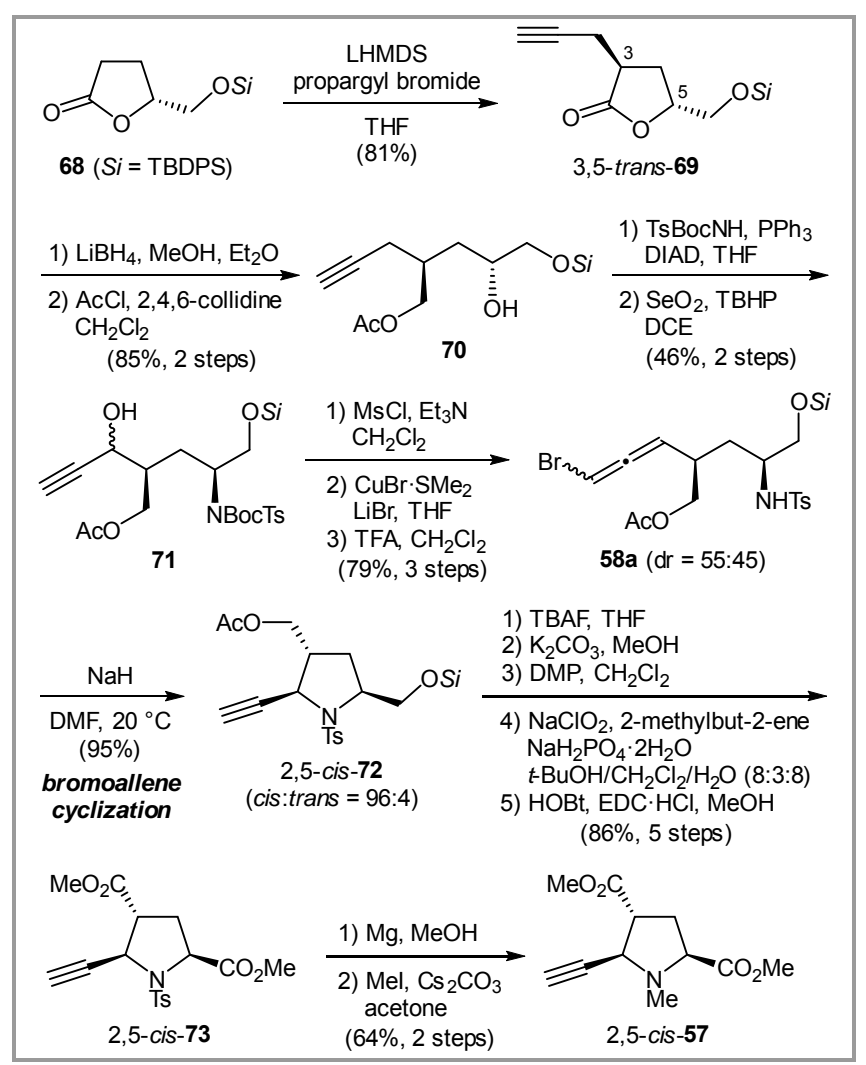

Scheme 22 Preparation of the Optically Active Pyrrolidine 57 via Bromoallene Cyclization. EDC $=N$-(3-dimethylaminopropyl)- $N$ 'ethylcarbodiimide, $\mathrm{HOBt}=1$-hydroxybenzotriazole.

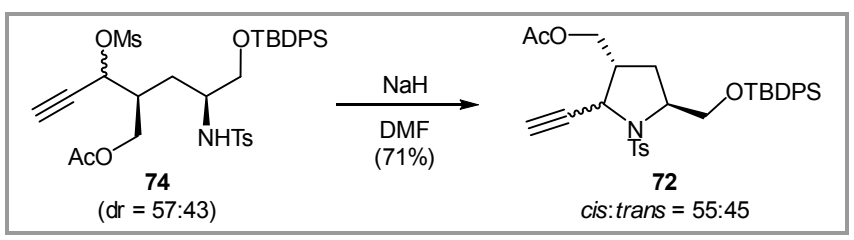

Scheme 23 Cyclization of Mesylate 74.

We then moved on to investigate the coupling of the two building blocks (R)-56a and 2,5-cis-57, and the construction of the quinocarcin core structure (Scheme 24). The treatment of an equimolar mixture of the two components with $\mathrm{Pd}\left(\mathrm{PPh}_{3}\right)_{4}, \mathrm{CuSO}_{4}$, and sodium ascorbate ${ }^{52}$ gave the coupling product $\mathbf{5 5 a}$ in $92 \%$ yield. Our initial attempt at the gold-catalyzed hydroamination using 55a, however, was not as efficient, and gave the desired product in up to $46 \%$ yield using $40 \mathrm{~mol} \%$ of cat. A (see Scheme 20). The lower yield observed in this case was attributed to unfavorable steric repulsion between the methyl ester at the C-5 position of the pyrrolidine and the $N$-Boc group in the conformer required for the hydroamination reaction. In contrast, the reaction of the corresponding amine $\mathbf{5 5 b}$ proceeded more efficiently upon treatment with cat. A. Following the stereoselective reduction of the unstable hydroamination product with $\mathrm{NaBH}_{3}(\mathrm{CN})$, the tetrahydroisoquinoline $\mathbf{7 5}$ was isolated in $90 \%$ yield. As expected, the secondary amine selectively underwent lactam formation with one of the ester groups when $\mathbf{7 5}$ was heated in the presence of $\mathrm{AcOH}$, leading to 53a with the diazabicyclo[3.2.1]octane core structure in $96 \%$ yield. 


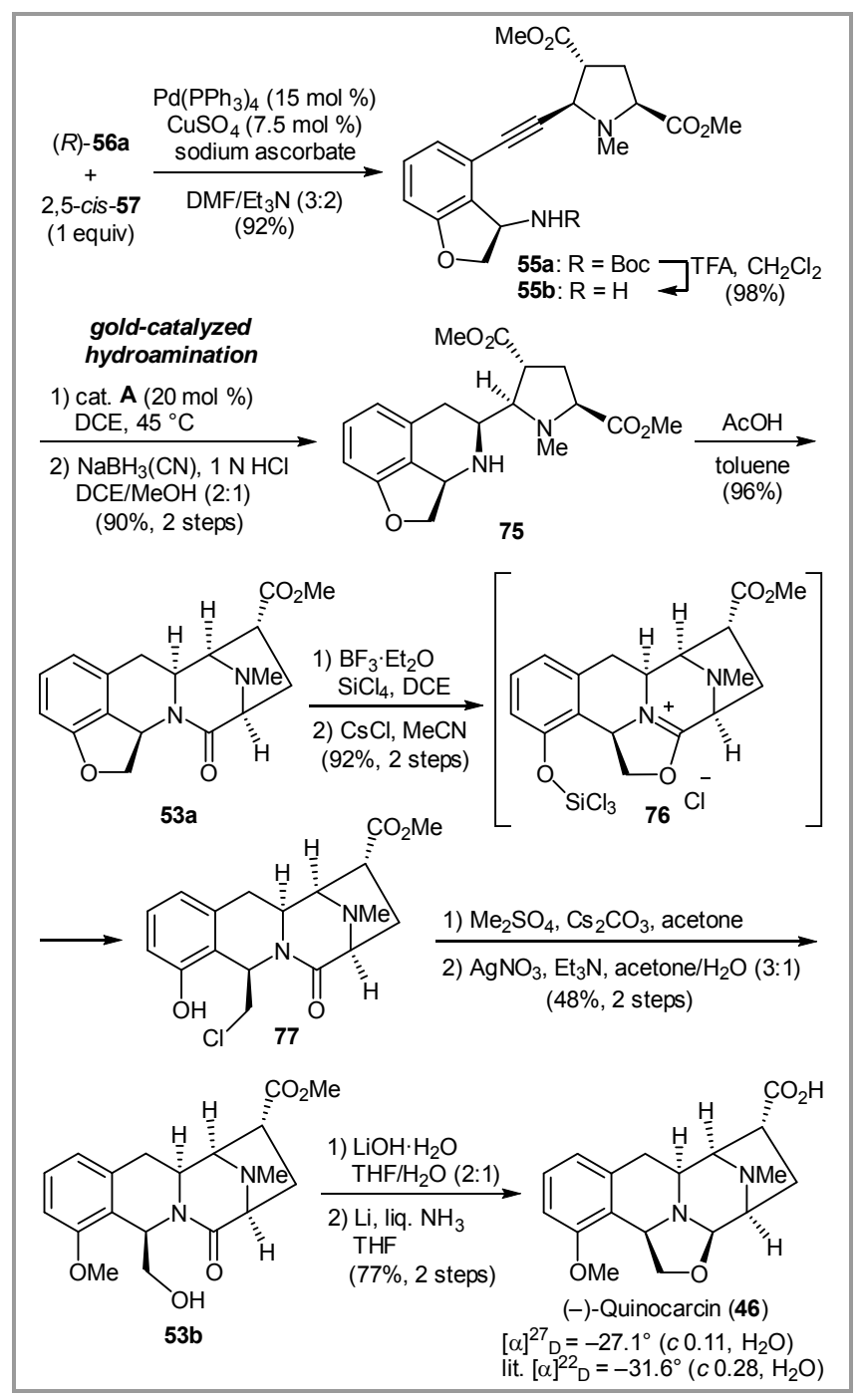

Scheme 24 Total Synthesis of Quinocarcin

The remaining task of affecting the unusual dihydrobenzofuran cleavage required thorough investigation. Based on the ring-opening iodination reaction of dihydrobenzofuran with $\mathrm{LiI}$ in the presence of $\mathrm{SiCl}_{4}$ and $\mathrm{BF}_{3} \cdot \mathrm{AcOH}$ reported by Zewge et al., ${ }^{53}$ we investigated the ring-opening reaction of 53a assisted by the neighboring lactam carbonyl group. ${ }^{54}$ It was envisaged that the treatment of lactam 53a with the Lewis acids (in the absence of LiI) would afford the oxazolidinium intermediate $\mathbf{7 6}$, which could be captured through an appropriate workup procedure. Unfortunately, however, the exposure of 53a to $\mathrm{BF}_{3} \cdot \mathrm{Et}_{2} \mathrm{O}$ and $\mathrm{SiCl}_{4}$ in $\mathrm{DCE}$ followed by an aqueous workup of the resulting suspension (presumably containing 76) only resulted in the recovery of the starting material 53a. The failure of the reaction in this particular case was attributed to the hydrolysis of the transient silyl ether in $\mathbf{7 6}$ prior to the required cleavage of the oxazolidinium, which effectively promoted the reverse reaction from $\mathbf{7 6}$ to 53a. Following a period of extensive experimentation using a variety of different Lewis acids, as well as investigating the capture of $\mathbf{7 6}$ through silane reduction and amidine formation, we found that the addition of an excess of $\mathrm{CsCl}$ to the reaction mixture after the ring-opening reaction gave the chlorinated phenol 77 containing the quinocarcin core structure in $92 \%$ yield. Subsequent conversion of 77 to the known amide 53b was achieved by the methylation of the phenol followed by hydrolysis of the carbon-chlorine bond in the presence of $\mathrm{AgNO}_{3}$ and $\mathrm{Et}_{3} \mathrm{~N}$. The total synthesis of quinocarcin was then completed using the procedure reported by Allan and Stoltz. ${ }^{39 g}$ The spectroscopic data for our synthetic (-)-quinocarcin were identical to those reported. ${ }^{35,39}$

\section{Concluding Remarks}

The work described herein demonstrates the enormous potential associated with the latest transition-metal catalyzed reactions for the synthesis of complex alkaloids. The highlights of the current work include the palladium-catalyzed cascade cyclization of allenes for the synthesis of ergot alkaloids and the gold(I)catalyzed hydroamination of alkynes for the synthesis of the tetrahydroisoquinoline alkaloid, quinocarcin. These examples show that the use of transition-metal catalyzed reactions can provide a platform for the development of novel synthetic approach towards a range of different alkaloids, containing the important structural elements, and possibly lead to better synthetic access to alkaloid derivatives that would otherwise be difficult to obtain using conventional organic chemistry.

\section{Acknowledgments}

This work was supported by a Grant-in-Aid for the Encouragement of Young Scientists (A) and Scientific Research on Innovative Areas "Integrated Organic Synthesis based on Reaction Integration: Development of New Methods and Creation of New Substances" (No. 2105). H.C. and S.I. are grateful for Research Fellowships from the Japan Society for the Promotion of Science (JSPS) for Young Scientists. H.C. also acknowledges JSPS for the Strategic Young Researcher Overseas Visits Program for Accelerating Brain Circulation.

\section{References}

(1) (a) Trost, B. M. Angew. Chem. Int. Ed. 1995, 34, 259281. (b) Trost, B. M. Acc. Chem. Res. 2002, 35, 695705. (c) Li, C.-J.; Trost, B. M. Proc. Natl. Acad. Sci. U.S.A. 2008, 105, 13197-13202. For recent reviews on cascade reactions, see: (d) Tietze, L. F. Chem. Rev. 1996, 96, 115-136. (e) Nicolaou, K. C.; Montagnon, T.; Snyder, S. A. Chem. Commun. 2003, 551-564. (f) Nicolaou, K. C.; Sorensen, E. J. Classics in Total Synthesis 1, Wiley-VCH: Weinheim, 1996, pp 641-653. (g) Müller, T. Metal Catalyzed Cascade Reactions, Vol. 19; Müller, T., Ed.; Springer: Berlin/Heidelberg, 2006, pp. 149-205. (h) Nicolaou, K. C.; Edmonds, D. J.; Bulger, P. G. Angew. Chem. Int. Ed. 2006, 45, 7134 7186. (i) Kirsch, S. F. Synthesis 2008, 3183-3204. (j) Lu, L.-Q.; Chen, J.-R.; Xiao, W.-J. Acc. Chem. Res. 2012, 45, 1278-1293. (k) Pellissier, H. Chem. Rev. 2013, 113, 442-524. (1) Majumdar, K. C.; Sinha, B. Synthesis 2013, 45, 1271-1299. (m) Ohno, H. Asian J. Org. Chem. 2013, 2, 18-28. 
(2) For isolation of lysergic acid, see: (a) Jacobs, W.; Craig, L. J. Biol. Chem. 1934, 104, 547-551. (b) Stoll, A.; Hofmann, A.; Troxler, F. Helv. Chim. Acta 1949, 32 , 506-521. For isolation of lysergol, see: (c) Agurell, S. Acta Pharm. Suecica 1965, 2, 357-374. For isolation of isolysergol, see: (d) Agurell, S. Acta Pharm. Suecica 1966, 3, 7-10

(3) (a) Ninomiya, I.; Kiguchi, T. The Alkaloids, Vol. 38; Brossi, A., Ed.; Academic Press: San Diego, CA, 1990, pp 1-156. (b) Somei, M.; Yokoyama, Y.; Murakami, Y.; Ninomiya, I.; Kiguchi, T.; Naito, T. The Alkaloids, Vol. 54; Cordell, G. A., Ed.; Academic Press: San Diego, CA, 2000, pp 191-257.

(4) For synthesis of racemic lysergic acid, see: (a) Kornfeld, E. C.; Fornefeld, E. J.; Kline, G. B.; Mann, M. J.; Morrison, D. E.; Jones, R. G.; Woodward, R. B. J. Am. Chem. Soc. 1956, 78, 3087-3114. (b) Julia, M.; LeGoffic, F.; Igolen, J.; Baillarge, M. Tetrahedron Lett. 1969, 10, 1569-1571. (c) Armstrong, V. W.; Coulton, S.; Ramage, R. Tetrahedron Lett. 1976, 17, 4311-4314. (d) Oppolzer, W.; Francotte, E.; Bättig, K. Helv. Chim. Acta 1981, 64, 478-481. (e) Rebek, J., Jr.; Tai, D. F. Tetrahedron Lett. 1983, 24, 859-860. (f) Kiguchi, T.; Hashimoto, C.; Naito, T.; Ninomiya, I. Heterocycles 1982, 19, 2279-2282. (g) Kurihara, T.; Terada, T.; Yoneda, R. Chem. Pharm. Bull. 1986, 34, 442-443. (h) Cacchi, S.; Ciattini, P. G.; Morera, E.; Ortar, G. Tetrahedron Lett. 1988, 29, 3117-3120. (i) Hendrickson, J. B.; Wang, J. Org. Lett. 2004, 6, 3-5. (j) Inuki, S.; Oishi, S.; Fujii, N.; Ohno, H. Org. Lett. 2008, 10, 5239 5242 .

(5) For synthesis of lysergol and isolysergol, see: (a) Kiguchi, T.; Hashimoto, C.; Ninomiya, I. Heterocycles 1985, 23, 1377-1380. (b) Ninomiya, I.; Hashimoto, C.; Kiguchi, T.; Naito, T.; Barton, D. H. R.; Lusinchi, X.; Milliet, P. J. Chem. Soc. Perkin Trans. 1 1990, 707-713 (c) Deck, J. A.; Martin, S. F. Org. Lett. 2010, 12, 26102613. See also, ref. $4 \mathrm{j}$ and $6 \mathrm{~d}$.

(6) For asymmetric synthesis of (+)-lysergic acid, see: (a) Moldvai, I.; Temesvári-Major, E.; Incze, M.; Szentirmay, É.; Gács-Baitz, E.; Szántay, C. J. Org. Chem. 2004, 69, 5993-6000. (b) Inoue, T.; Yokoshima, S.; Fukuyama, T. Heterocycles 2009, 79, 373-378. (c) Kurokawa, T.; Isomura, M.; Tokuyama, H.; Fukuyama, T. Synlett 2009, 775-778. (d) Inuki, S.; Iwata, A.; Oishi, S.; Fujii, N.; Ohno, H. J. Org. Chem. 2011, 76, 2072-2084. (e) Liu, Q.; Jia, Y. Org. Lett. 2011, 13, 4810-4813. For our formal synthesis, see: (f) Iwata, A.; Inuki, S.; Oishi, S.; Fujii, N.; Ohno, H. J. Org. Chem. 2011, 76, 5506-5512.

(7) For pioneering works on palladium-catalyzed reactions of allenes, see: (a) Shimizu, I.; Tsuji, J. Chem. Lett. 1984, 233-236. (b) Larock, R. C.; Berrios-Peña, N. G.; Fried, C. A. J. Org. Chem. 1991, 56, 2615-2617. (c) Davies, I. W.; Scopes, D. I. C.; Gallagher, T. Synlett 1993, 85-87. For reviews, see: (a) Zimmer, R.; Dinesh, C. U.; Nandanan, E.; Khan, F. A. Chem. Rev. 2000, 100, 3067 3125. (b) Alcaide, B.; Almendros, P. Adv. Synth. Catal. 2011, 353, 2561-2576. (c) Yu, S.; Ma, S. Angew. Chem. Int. Ed. 2012, 51, 3074-3112.

(9) (a) Ohno, H.; Miyamura, K.; Takeoka, Y.; Tanaka, T. Angew. Chem. Int. Ed. 2003, 42, 2647-2650. (b) Ohno, H.; Miyamura, K.; Mizutani, T.; Kadoh, Y.; Takeoka, Y.; Hamaguchi, H.; Tanaka, T. Chem. Eur. J. 2005, 11, 3728-3741. See also: (c) Ohno, H.; Takeoka, Y.; Miyamura, K.; Kadoh, Y.; Tanaka, T. Org. Lett. 2003, 5, 4763-4766. (d) Ohno, H.; Takeoka, Y.; Kadoh, Y.; Miyamura, K.; Tanaka, T. J. Org. Chem. 2004, 69, $4541-4544$.
(10) Okano, A.; Mizutani, T.; Oishi, S.; Tanaka, T.; Ohno, H.; Fujii, N. Chem. Commun. 2008, 3534-3536.

(11) (a) Grigg, R.; Köppen, I.; Rasparini, M.; Sridharan, V. Chem. Commun. 2001, 964-965. For biscyclization reactions of the related allenamides, see: (b) Beccalli, E. M.; Broggini, G.; Clerici, F.; Galli, S.; Kammerer, C.; Rigamonti, M.; Sottocornola, S. Org. Lett. 2009, 11, 1563-1566. (c) Beccalli, E. M.; Bernasconi, A.; Borsini, E.; Broggini, G.; Rigamonti, M.; Zecchi, G. J. Org. Chem. 2010, 75, 6923-6932. For a related reaction, see: (d) Broggini, G.; Borsini, E.; Fasana, A.; Poli, G.; Liron, F. Eur. J. Org. Chem. 2012, 3617-3624.

(12) (a) Hiroi, K.; Hiratsuka, Y.; Watanabe, K.; Abe, I.; Kato, F.; Hiroi, M. Synlett 2001, 263-265. For the asymmetric version, see: (b) Hiroi, K.; Hiratsuka, Y.; Watanabe, K.; Abe, I.; Kato, F.; Hiroi, M. Tetrahedron: Asymmetry 2002, 13, 1351-1353. For biscyclization of the related 2-iodobenzamides, see: (c) Watanabe, K.; Hiroi, K. Heterocycles 2003, 59, 453-457.

(13) (a) Johnson, W. S.; Frei, B.; Gopalan, A. S. J. Org. Chem. 1981, 46, 1512-1513. (b) Anderson, N. H.; Denniston, A. D.; McCrae, D. A. J. Org. Chem. 1982, 47, 1145-1146.

(14) Corey, E. J.; Erickson, B. W. J. Org. Chem. 1971, 36 $3553-3560$

(15) Ireland, R. E.; Wipf, P.; Xiang, J. N. J. Org. Chem. 1991, 56, 3572-3582.

(16) Sherry, B. D.; Toste, F. D. J. Am. Chem. Soc. 2004, 126, 15978-15979.

(17) Bach, T.; Kather, K. J. Org. Chem. 1996, 61, 7642-7643.

(18) For recent books and reviews on palladium-catalyzed cyclization of allenes, see: (a) Yamamoto, Y.; Radhakrishnan, U. Chem. Soc. Rev. 1999, 28, 199-207. (b) Zimmer, R.; Dinesh, C. U.; Nandanan, E.; Khan, F. A. Chem. Rev. 2000, 100, 3067-3125. (c) Bates, R. W.; Satcharoen, V. Chem. Soc. Rev. 2002, 31, 12-21. (d) Ma, S. Acc. Chem. Res. 2003, 36, 701-712. (e) Mandai, T. Modern Allene Chemistry, Vol. 2; Krause, N.; Hashmi, A. S. K., Eds.; Wiley-VCH: Weinheim, 2004, pp. 925972. (f) Ohno, H. Chem. Pharm. Bull. 2005, 53, 12111226. (g) Ma, S. Chem. Rev. 2005, 105, 2829-2871. (h) Brummond, K. M.; DeForrest, J. E. Synlett 2007, 795818. (i) Aubert, C.; Fensterbank, L.; Garcia, P.; Malacria, M.; Simonneau, A. Chem. Rev. 2011, 111, 1954-1993. (j) Alcaide, B.; Almendros, P. Adv. Synth. Catal. 2011, 353, 2561-2576. (k) Lu, T.; Lu, Z.; Ma, Z.-X.; Zhang, Y. Hsung, R. P. Chem. Rev. 2013, 113, 4862-4904. See also, ref. 8

(19) (a) Lathbury, D.; Vernon, P.; Gallagher, T. Tetrahedron Lett. 1986, 27, 6009-6012. (b) Prasad, J. S.; Liebeskind, L. S. Tetrahedron Lett. 1988, 29, 4257-4260. (c) Fox, D. N. A.; Lathbury, D.; Mahon, M. F.; Molloy, K. C.; Gallagher, T. J. Am. Chem. Soc. 1991, 113, 2652-2656. (d) Kimura, M.; Fugami, K.; Tanaka, S.; Tamaru, Y. J. Org. Chem. 1992, 57, 6377-6379. (e) Karstens, W. F. J.; Rutjes, F. P. J. T.; Hiemstra, H. Tetrahedron Lett. 1997, 38, 6275-6278. (f) Karstens, W. F. J.; Stol, M.; Rutjes, F. P. J. T.; Hiemstra, H. Synlett 1998, 1126-1128. (g) Ma, S.; Gao, W. Org. Lett. 2002, 4, 2989-2992. (h) Ma, S.; Yu, F.; Li, J.; Gao, W. Chem. Eur. J. 2007, 13, 247-254.

(20) For representative examples, see: (a) Kang, S.-K.; Baik, T.-G.; Kulak, A. N. Synlett 1999, 324-326. (b) Rutjes, F. P. J. T.; Tjen, K. C. M. F.; Wolf, L. B.; Karstens, W. F. J.; Schoemaker, H. E.; Hiemstra, H. Org. Lett. 1999, 1, 717-720. (c) Ohno, H.; Toda, A.; Miwa, Y.; Taga, T.; Osawa, E.; Yamaoka, Y.; Fujii, N.; Ibuka, T. J. Org. Chem. 1999, 64, 2992-2993. (d) Kang, S.-K.; Kim, K.-J. Org. Lett. 2001, 3, 511-514. (e) Ohno, H.; Anzai, M.; Toda, A.; Oishi, S.; Fujii, N.; Tanaka, T.; Takemoto, Y.; 
Ibuka, T. J. Org. Chem. 2001, 66, 4904-4914. (f) Grigg, R.; Inman, M.; Kilner, C.; Köppen, I.; Marchbank, J.; Selby, P. Sridharan, V. Tetrahedron 2007, 63, 61526169. (g) Cheng, X.; Ma, S. Angew. Chem. Int. Ed. 2008, 47, 4581-4583. (h) Shu, W.; Ma, S. Chem. Commun. 2009, 6198-6200. See also: (i) Stevens, R. R.; Shier, G. D. J. Organometal. Chem. 1970, 21, 495-499.

(21) Myers, A. G.; Zheng, B. J. Am. Chem. Soc. 1996, 118, 4492-4493.

(22) Ohno, H.; Hamaguchi, H.; Ohata, M.; Kosaka, S.; Tanaka, T. J. Am. Chem. Soc. 2004, 126, 8744-8754.

(23) (a) Ohno, H.; Hamaguchi, H.; Tanaka, T. Org. Lett. 2000, 2, 2161-2163. (b) Ohno, H.; Hamaguchi, H.; Tanaka, T. J. Org. Chem. 2001, 66, 1867-1875.

(24) (a) Garner, P. Tetrahedron Lett. 1984, 25, 5855-5858. (b) Campbell, A. D.; Raynham, T. M.; Taylor, R. J. K. Synthesis 1998, 1707-1709.

(25) Hofmeister, H.; Annen, K.; Laurent, H.; Wiechert, R. Angew. Chem. Int. Ed. Engl. 1984, 23, 727-729.

(26) Kimura, M.; Futamata, M.; Mukai, R.; Tamaru, Y. J. Am. Chem. Soc. 2005, 127, 4592-4593.

(27) Imamoto, T.; Kusumoto, T.; Yokoyama, M. J. Chem. Soc. Chem. Commun. 1982, 1042-1044.

(28) Takita, R.; Yakura, K.; Ohshima, T.; Shibasaki, M. J. Am. Chem. Soc. 2005, 127, 13760-13761.

(29) (a) Lu, G.; Li, X.; Chan, W. L.; Chan, A. S. C. Chem. Commun. 2002, 172-173. (b) Gao, G.; Moore, D.; Xie, R.-G.; Pu, L. Org. Lett. 2002, 4, 4143-4146. (c) Evans, P. A.; Cui, J.; Gharpure, S. J.; Polosukhin, A.; Zhang, H.-R. J. Am. Chem. Soc. 2003, 125, 14702-14703.

(30) (a) Okude, Y.; Hirano, S.; Hiyama, T.; Nozaki, H. J. Am. Chem. Soc. 1977, 99, 3179-3181. (b) Jin, H.; Uenishi, J.; Christ, W. J.; Kishi, Y. J. Am. Chem. Soc. 1986, 108, 5644-5646. (c) Takai, K.; Tagashira, M.; Kuroda, T.; Oshima, K.; Utimoto, K.; Nozaki, H. J. Am. Chem. Soc. 1986, 108, 6048-6050.

(31) (a) Wan, Z.-K.; Choi, H.-W.; Kang, F.-A.; Nakajima, K.; Demeke, D.; Kishi, Y. Org. Lett. 2002, 4, 4431-4434.

(b) Choi, H.-W.; Nakajima, K.; Demeke, D.; Kang, F.A.; Jun, H.-S.; Wan, Z.-K.; Kishi, Y. Org. Lett. 2002, 4 , 4435-4438. (c) Namba, K.; Kishi, Y. Org. Lett. 2004, 6, 5031-5033.

(32) Midland, M. M.; Tramontano, A.; Kazubski, A.; Graham, R. S.; Tsai, D. J. S.; Cardinv, D. B. Tetrahedron 1984, 40,1371-1380.

(33) Stoll, A.; Hofmann, A.; Schlientz, W. Helv. Chim. Acta 1949, 32, 1947-1956.

(34) Lysergic acid is known to racemize under harsh basic conditions, see: (a) Smith, S.; Timmis, G. M. J. Chem. Soc. 1936, 1440-1444. (b) Moldvai, I.; Gács-Baitz, E.; Temesvári-Major, E.; Russo, L.; Pápai, I.; Rissanen, K.; Szárics, É.; Kardos, J.; Szántay, C. Heterocycles 2007, $71,1075-1095$

(35) (a) Tomita, F.; Takahashi, K.; Shimizu, K. J. Antibiot. 1983, 463-467. (b) Takahashi, K.; Tomita, F. J. Antibiot. 1983, 468-470. (c) Tomita, F.; Takahashi, K.; Tamaoki, T. J. Antibiot. 1984, 1268-1272.

(36) For reviews on tetrahydroisoquinoline alkaloids and their derivatives, see: (a) Scott, J. D.; Williams, R. M. Chem. Rev. 2002, 102, 1669-1730. (b) Chrzanowska, M.; Rozwadowska, M. D. Chem. Rev. 2004, 104, 33413370. (c) Siengalewicz, P.; Rinner, U.; Mulzer, J. Chem. Soc. Rev. 2008, 37, 2676-2690.

(37) (a) Ryan, D. P.; Supko, J. G.; Eder, J. P.; Seiden, M. V.; Demetri, G.; Lynch, T. J.; Fischman, A. J.; Davis, J.; Jimeno, J.; Clark, J. W. Clin. Cancer Res. 2001, 7, 231242. (b) Sessa, C.; De Braud, F.; Perotti, A.; Bauer, J.; Curigliano, G.; Noberasco, C.; Zanaboni, F.; Gianni, L.; Marsoni, S.; Jimeno, J.; D'Incalci, M.; Dall'ó, E.;
Colombo, N. J. Clin. Oncol. 2005, 23, 1867-1874. (c)

Soares, D. G.; Escargueil, A. E.; Poindessous, V.;

Sarasin, A.; De Gramont, A.; Bonatto, D.; Henriques, J. A. P.; Larsen, A. Proc. Natl. Acad. Sci. U.S.A. 2007, 104, 13062-13067.

(38) For the total synthesis of ( \pm )-quinocarcin, see: Fukuyama, T.; Nunes, J. J. J. Am. Chem. Soc. 1988, 110, 5196-5198.

(39) For the total syntheses of (-)-quinocarcin, see: (a) Garner, P.; Ho, W. B.; Shin, H. J. Am. Chem. Soc. 1992, 114, 2767-2768. (b) Garner, P.; Ho, W. B.; Shin, H. J. Am. Chem. Soc. 1993, 115, 10742-10753. (c) Katoh, T.; Kirihara, M.; Nagata, Y.; Kobayashi, Y.; Arai, K.; Minami, J.; Terashima, S. Tetrahedron 1994, 50, 62396258. (d) Katoh, T.; Terashima, S. Pure Appl. Chem. 1996, 68, 703-706. (e) Kwon, S.; Myers, A. G. J. Am. Chem. Soc. 2005, 127, 16796-16797. (f) Wu, Y.-C.; Liron, M.; Zhu, J. J. Am. Chem. Soc. 2008, 130, 71487152. (g) Allan, K. M.; Stoltz, B. M. J. Am. Chem. Soc. 2008, 130, 17270-17271. (h) Chiba, H.; Oishi, S.; Fujii, N.; Ohno, H. Angew. Chem. Int. Ed. 2012, 51, 91699172. (i) Chiba, H.; Sakai, Y.; Ohara, A.; Oishi, S.; Fujii, N.; Ohno, H. Chem. Eur. J. 2013, 19, 8875-8883.

(40) For other recent examples, see: (a) Dong, W.; Liu, W.; Liao, X.; Guan, B.; Chen, S.; Liu, Z. J. Org. Chem. 2011, 76, 5363-5368. (b) Yoshida, A.; Akaiwa, M.; Asakawa, T.; Hamashima, Y.; Yokoshima, S.; Fukuyama, T.; Kan, T. Chem. Eur. J. 2012, 18, 11192-11195. (c) Magnus, P.; Matthews, K. S. Tetrahedron 2012, 68, 6343-6360.

(41) For reviews on transition-metal-catalyzed hydroamination of alkynes, see: (a) Alonso, F.; Beletskaya, I. P.; Yus, M. Chem. Rev. 2004, 104, 3079 3160. (b) Severin, R.; Doye, S. Chem. Soc. Rev. 2007, $36,1407-1420$

(42) For reviews on gold-catalyzed hydroamination of alkynes, see: (a) Hashmi, A. S. K.; Hutchings, G. J. Angew. Chem. Int. Ed. 2006, 45, 7896-7936. (b) Fürstner, A.; Davies, P. W. Angew. Chem. Int. Ed. 2007, 46, 3410-3449. (c) Hashmi, A. S. K. Chem. Rev. 2007, 107, 3180-3211. (d) Jiménez-Núñez, E.; Echavarren, A. M. Chem. Commun. 2007, 333-346. (e) Kirsch, S. F. Synthesis 2008, 3183. (f) Das, A.; Sohel, S. M. A.; Liu, R.-S. Org. Biomol. Chem. 2010, 8, 960-979. (g) Shapiro, N. D.; Toste, F. D. Synlett 2010, 675-691. (h) Krause, N.; Winter, C. Chem. Rev. 2011, 111, 1994-2009. (i) Patil, N. T.; Singh, V. J. Organomet. Chem. 2011, 696, 419-432.

(43) (a) Ohno, H.; Ohta, Y.; Oishi, S.; Fujii, N. Angew. Chem. Int. Ed. 2007, 46, 2295-2298. (b) Ohta, Y.; Chiba, H.; Oishi, S.; Fujii, N.; Ohno, H. Org. Lett. 2008, 10, 35353538. (c) Ohta, Y.; Oishi, S.; Fujii, N.; Ohno, H. Org. Lett. 2009, 11, 1979-1982. (d) Suzuki, Y.; Ohta, Y.; Oishi, S.; Fujii, N.; Ohno, H. J. Org. Chem. 2009, 74, 4246-4251. (e) Ohta, Y.; Chiba, H.; Oishi, S.; Fujii, N.; Ohno, H. J. Org. Chem. 2009, 74, 7052-7058. (f) Suzuki, Y.; Naoe, S.; Oishi, S.; Fujii, N.; Ohno, H. Org. Lett. 2012, 14, 326-329.

(44) (a) Ohta, Y.; Oishi, S.; Fujii, N.; Ohno, H. Chem. Commun. 2008, 835-837. (b) Ohta, Y.; Kubota, Y.; Watabe, T.; Chiba, H.; Oishi, S.; Fujii, N.; Ohno, H. J. Org. Chem. 2009, 74, 6299-6302. (c) Tokimizu, Y.; Ohta, Y.; Chiba, H.; Oishi, S.; Fujii, N.; Ohno, H. Tetrahedron 2011, 67, 5168-5175.

(45) (a) Hirano, K.; Inaba, Y.; Watanabe, T.; Oishi, S.; Fujii, N.; Ohno, H. Adv. Synth. Catal. 2010, 352, 368-372. (b) Hirano, K.; Inaba, Y.; Takahashi, N.; Shimano, M.; Oishi, S.; Fujii, N.; Ohno, H. J. Org. Chem. 2011, 76, 1212-1227. (c) Hirano, K.; Inaba, Y.; Takasu, K.; Oishi, 
S.; Takemoto, Y.; Fujii, N.; Ohno, H. J. Org. Chem. 2011, 76, 9068-9080.

(46) For our other related works, see: (a) Watanabe, T.; Oishi, S.; Fujii, N.; Ohno, H. Org. Lett. 2007, 9, 4821-4824.

(b) Naoe, S.; Suzuki, Y.; Hirano, K.; Inaba, Y.; Oishi, S.; Fujii, N.; Ohno, H. J. Org. Chem. 2012, 77, 4907-4916.

(47) Ohno, H.; Ando, K.; Hamaguchi, H.; Takeoka, Y.; Tanaka, T. J. Am. Chem. Soc. 2002, 124, 15255-15266.

(48) (a) Hentges, S. G.; Sharpless, K. B. J. Am. Chem. Soc. 1980, 102, 4263-4265. (b) Hentges, S. G.; Sharpless, K. B. Chem. Rev. 1994, 94, 2483-2547.

(49) Lal, B.; Pramanik, B. N.; Manhas, M. S.; Bose, A. K. Tetrahedron Lett. 1977, 18, 1977-1980.

(50) Bartra, M.; Bou, V.; Garcia, J.; Urpi, F.; Vilarrasa, J. J. Chem. Soc. Chem. Commun. 1988, 270-272.

(51) (a) Montury, M.; Goré, J. Synth. Commun. 1980, 10, 873-879. (b) Elsevier, C. J.; Meijer, J.; Tadema, G.; Stehouwer, P. M.; Bos, H. J. T.; Vermeer, P. J. Org. Chem. 1982, 47, 2194-2196.

(52) Bag, S. S.; Kundu, R.; Das, M. J. Org. Chem. 2011, 76, 2332-2337.

(53) Zewge, D.; King, A.; Weissman, S.; Tschaen, D. Tetrahedron Lett. 2004, 45, 3729-3732.

(54) Chiba, H.; Sakai, Y.; Oishi, S.; Fujii, N. Ohno, H. Tetrahedron Lett. 2012, 53, 6273-6276. 
Hiroaki Ohno was born in 1973, and grew up in Kushiro, Hokkaido, Japan. He graduated with a B.Sc in Pharmaceutical Sciences from Kyoto University in 1996. Following on from his doctoral work in the same University (1996-1999; as a Japan Society for the Promotion of Science [JSPS] Research Fellow during 1999) under the direction of Professor Toshiro Ibuka, he joined the research group of Professor Tetsuaki Tanaka at Osaka University as a Research Associate in 1999. He received his Ph.D. from Kyoto University (2002) and the Pharmaceutical Society of Japan Award for Young Scientists (2005). He began his work as an Associate Professor at Kyoto University (Professor Nobutaka Fujii's research group) in 2005. His research interests include the development of transitionmetal-catalyzed cascade reactions, as well as the synthesis of biologically active compounds and their application to drug discovery.

Hiroaki Chiba was born in 1986, and grew up in Hiroshima, Japan. He completed his undergraduate degree in 2008, and then started his Ph.D studies under Professors Nobutaka Fujii and Hiroaki Ohno at Kyoto University (as a JSPS Research Fellow during 2010-2013). His thesis was on the total synthesis of tetrahydroisoquinoline alkaloids via gold-catalyzed regioselective hydroamination, for which he was nominated as a finalist for the Reaxys Ph.D prize in 2013. In the same year, he joined Professor Dean Toste's research group at the University of California, Berkeley, as a postdoctoral fellow (2013-present; by Strategic Young Researcher Overseas Visit Program from JSPS). His current research involves the development of useful asymmetric reactions using chiral gold complexes.

Shinsuke Inuki was born in 1982 at Himeji, Japan. He graduated with a B.Sc in Pharmaceutical Sciences from Kyoto University in 2006 and initiated his doctoral course study under the supervision of Professors Nobutaka Fujii and Hiroaki Ohno (as a JSPS Research Fellow during 2008-2011). His thesis was on the total synthesis of bioactive natural products using the palladium-catalyzed cascade cyclization of allenes and related compounds, which was published by Springer with the honor of the Springer Thesis prize (ISBN: 978-4-431-54043-4). He is now working for Fujifilm corporation, as a researcher.

Shinya Oishi received his BSc (1998) and Ph.D (2003) in Pharmaceutical Science from Kyoto University under the direction of Professor Nobutaka Fujii. He then studied as a JSPS postdoctoral fellow with Dr. Terrence R. Burke, Jr. at the National Cancer Institute, NIH, USA. In 2004, he moved to the Center for Drug Discovery at the University of Shizuoka as a lecturer. He returned to Kyoto University in 2006 to serve as an assistant professor at the Graduate School of Pharmaceutical Sciences, and was subsequently promoted to senior lecturer in 2009 . He is currently working on the medicinal chemistry of a wide range of anticancer and antiviral agents.

Nobutaka Fujii was born in 1950 at Kudamatsu, Yamaguchi, Japan. He graduated with a B.Sc in Pharmaceutical Sciences from Kyoto University in 1972 and initiated his doctoral course study under the supervision of Emeritus Professor Haruaki Yajima. He received his Ph.D from Kyoto University in 1980 and the Pharmaceutical Society of Japan Award for Young Scientists (1988). He started his academic career as a Research Associate (1975), followed by Associate Professor (1980), and Full Professor (1989) at the same university. During this period, he was appointed as a Visiting Associate of the NIH/FDA (1984-1986) and was involved in collaborating with Dr. Teh-Yung Liu's research group. He was nominated as the Dean of the Graduate School of Pharmaceutical Sciences (2008) and an Executive Vice President (2008-2010) in Kyoto University. More recently, he is continuing his research as a Distinguished Professor (2010-present) at the same university. His research interests include peptide/protein-based chemical biology, the development of synthetic methods for the construction of peptide isosteres and their application in peptide-lead drug discovery, and medicinal chemistry targeting anti-cancer and anti-virus therapeutics.

Short Title: Syntheses of Alkaloids by Transition-Metal-Catalyzed Amination<smiles>CN1CC(C(=O)O)C=C2c3cccc4[nH]cc(c34)C[C@H]2C1</smiles>

(+)-Lysergic acid
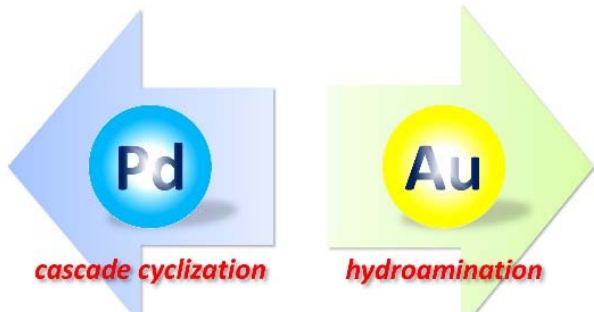

hydroamination intramolecular amination

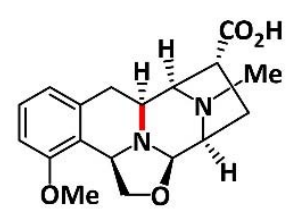

(-)-Quinocarcin 